\title{
Selective Inhibition of Kindling Development by Intraventricular Administration of TrkB Receptor Body
}

\author{
Devin K. Binder, ${ }^{1}$ Mark J. Routbort, ${ }^{1}$ Terence E. Ryan, ${ }^{5}$ George D. Yancopoulos, ${ }^{5}$ and \\ James O. McNamara1,2,3,4 \\ Departments of ${ }^{1}$ Neurobiology, ${ }^{2}$ Medicine (Neurology), ${ }^{3}$ Pharmacology, and ${ }^{4}$ Molecular Cancer Biology, Duke University \\ Medical Center, Durham, North Carolina 27710, and ${ }^{5}$ Regeneron Pharmaceuticals, Tarrytown, New York 10591
}

Recent work has shown that neurotrophin gene expression is increased after seizures evoked in the kindling model of epilepsy, but whether neurotrophins regulate kindling development is as yet unclear. In this study, we attempted to block selectively the activation of distinct neurotrophin receptors throughout kindling development in the rat via chronic intracerebroventricular administration of trk receptor bodies. The efficacy and selectivity of the trk receptor bodies were established by inhibition of neurotrophin-induced trk receptor phosphorylation in pheochromocytoma (PC12) cells and primary cultures of cortical neurons. The intracerebroventricular infusion of trkB receptor body (trkB-Fc) inhibited development of kindling in comparison with that seen with saline or human IgG controls, trkA-Fc, or trkC-Fc. These results imply that activation of trkB receptors contributes to the development of kindling, a form of activitydependent behavioral plasticity in the adult mammalian brain.

Key words: neurotrophins; BDNF; kindling; epilepsy; epileptogenesis; trk receptors
Physiological forms of neuronal activity underlie experiencedependent plasticities required for the normal development of the mammalian nervous system (Hubel and Wiesel, 1965). Similarly, pathological forms of neuronal activity can be used to induce anatomic and behavioral plasticities experimentally in the mature nervous system that serve as models of human disease (Routbort and McNamara, 1996). One example is the kindling model of epilepsy, in which brief changes in neuronal activity lead to lifelong structural and functional modification of the mammalian brain (Goddard et al., 1969). Kindling is commonly induced by focal application of a low-intensity electrical stimulus that initially evokes a brief localized electrical seizure without behavioral change; however, after repeated applications, the low-intensity stimulus evokes prolonged and widespread electrical seizures accompanied by intense behavioral seizures (McNamara et al., 1993). After it is established, this hyperexcitable state persists for the life of the animal. Understanding the cellular and molecular mechanisms mediating the development of epilepsy (epileptogenesis) in this animal model may lead to prophylaxis of human epilepsies.

Because of the discovery (Gall and Isackson, 1989) that limbic seizures upregulate the mRNA for nerve growth factor, the speculation has arisen that neurotrophic factor upregulation induced by seizures may contribute to the long-term structural and functional changes underlying the kindled state (Gall, 1993). Multiple investigators have found that the expression of genes encoding neurotrophic factors and their receptors is prominently regulated by seizure activity. In particular, mRNA content of brain-derived neurotrophic factor (BDNF), nerve growth factor (NGF), and the high-affinity receptor (trkB) for BDNF and neurotrophin-4 (NT-4)

\footnotetext{
Received June 29, 1998; revised Nov. 2, 1998; accepted Nov. 27, 1998.

This work was supported by National Institutes of Health Grant NS-17771 (J.O.M.). We would like to thank S. Janumpalli and W. Qian for technical assistance and J. Rudge for helpful comments.

Correspondence should be addressed to Dr. James O. McNamara, 401 Bryan Research Building, Durham, NC 27710.

Copyright (C) 1999 Society for Neuroscience $\quad 0270-6474 / 99 / 191424-13 \$ 05.00 / 0$
}

is increased in kindling and other seizure models, whereas mRNA content of neurotrophin-3 (NT-3) is decreased (Ernfors et al., 1991; Gall et al., 1991, 1994; Isackson et al., 1991; DugichDjordjevic et al., 1992a,b; Bengzon et al., 1993; Humpel et al., 1993, 1994; Merlio et al., 1993; Bugra et al., 1994; Schmidt-Kastner and Olson, 1995; Mudo et al., 1996; Sato et al., 1996; for review, see Gall, 1993). The magnitude of increase is greatest for BDNF mRNA in the hippocampus, especially in the dentate gyrus (Lindvall et al., 1994; Sato et al., 1996). This upregulation has been demonstrated recently at the protein level as well. Extracts and in vivo microdialysates from animals given chemical convulsions show marked increases in neurotrophic activity (Lowenstein et al., 1993; Humpel et al., 1995). Seizures have been shown to induce NGF and bFGF immunoreactivity and protein content (Bengzon et al., 1992; Van Der Wal et al., 1994); increases in BDNF protein content have been described after both hilar lesion-induced limbic seizures and kindling (Nawa et al., 1995; Elmer et al., 1996). Finally, recent evidence indicating that NGF is released from hippocampal neurons minutes after depolarization (Blochl and Thoenen, 1995) suggests that neurotrophins may also be released acutely after seizure activity.

Notwithstanding this circumstantial evidence, little direct evidence addresses whether or how neurotrophins might regulate kindling development. Funabashi et al. (1988) and Van der Zee et al. (1995) found that kindling development was delayed by intraventricular infusion of anti-NGF antisera; however, the lack of specificity of the antisera limited interpretation of these experiments. Kokaia et al. (1995) found a marked delay of kindling development in BDNF heterozygous mice $(+/-)$ in which one BDNF allele had been inactivated by gene targeting; however, the extent to which the reduction of BDNF during development contributed to the phenotype studied in the mature mouse is uncertain. Thus, whether or how trk receptor activation is related functionally to kindling development is as yet unclear.

We attempted to block selectively activation of distinct neurotrophin receptors during kindling development in adult animals 

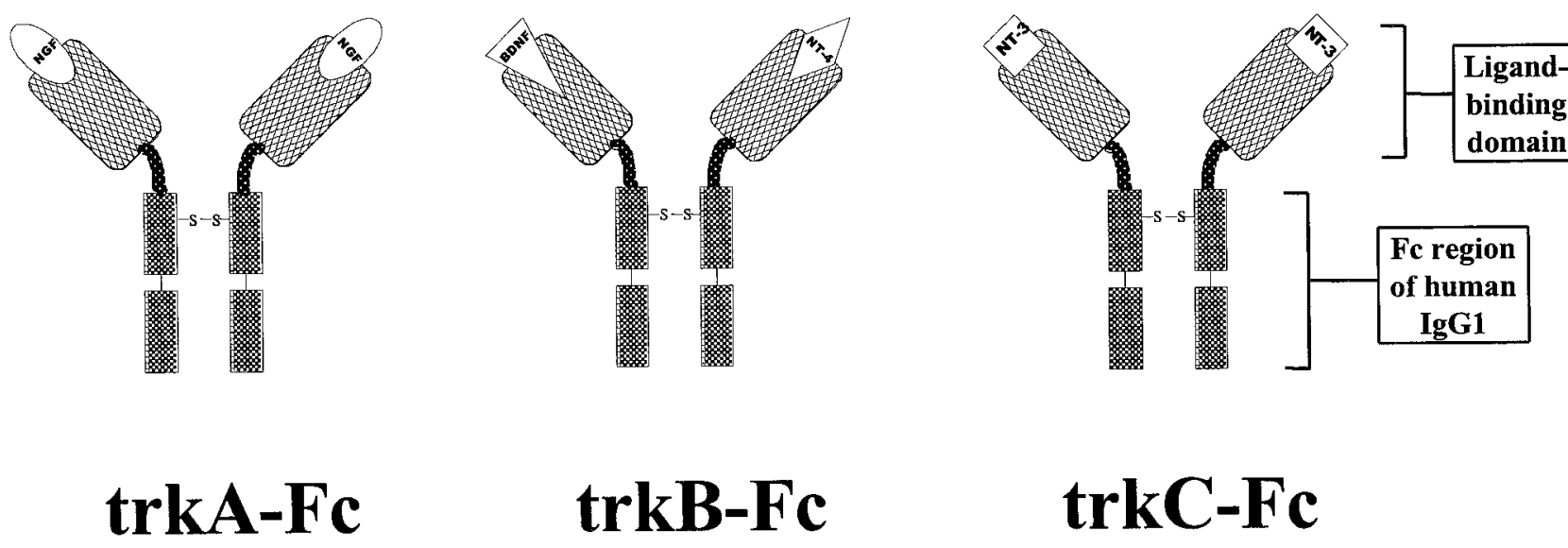

Figure 1. Structure of trk receptor bodies. The structure is a divalent homodimer containing two trk $(\operatorname{trk} A, \operatorname{trk} B$, or $\operatorname{trk} C)$ extracellular ligand-binding domains linked via hinge regions to the human $I g G 1 F c$ region. The putative function is to compete with native trk receptors for endogenous ligand(s) to sequester ligand(s) and prevent trk receptor activation.

using trk-specific "receptor bodies." These compounds are divalent homodimers that contain the ligand-binding domain of a given trk receptor followed by the hinge and $\mathrm{Fc}_{\gamma}$ region of human IgG1 (Glass et al., 1996) and thus act as false receptors or receptor bodies that putatively sequester endogenous neurotrophin (Fig. 1). In previous studies, these molecules have been shown to be highly potent and specific antagonists of their cognate neurotrophins in vitro (Shelton et al., 1995). In this study, we directly compared the functional relevance of various trk neurotrophin receptors in kindling development in the adult rat via chronic intracerebroventricular administration of trkA versus trkB versus trkC receptor bodies.

\section{MATERIALS AND METHODS}

Production and purification of trk receptor bodies. Baculovirus expression vectors encoding trkA-Fc, trkB-Fc, and trkC-Fc produced fusion proteins in which the ectodomains of rat trkA, trkB, or trkC were linked to a spacer with the sequence Gly-Pro-Gly, followed by the hinge, $\mathrm{CH} 2$, and $\mathrm{CH} 3$ regions of human $\mathrm{IgG} 1$, beginning with the residues Glu-Pro-Lys, as described (Davis et al., 1994). Baculovirus infections into Spodoptera frugiperda SF-21AE insect cells were performed by standard methods (Stitt et al., 1995). The soluble Fc-containing proteins were purified by protein A-Sepharose (Pharmacia, Piscataway, NJ) chromatography.

Cell culture and Western blot analysis. Pheochromocytoma (PC12) cells were grown in six-well plates using RPMI medium supplemented with $10 \%$ fetal bovine serum. Primary dissociated cortical cultures were prepared from embryonic day 18 rat embryos and grown as described previously (Patel et al., 1996). Cortical cells were plated in six-well plates and treated after $5 \mathrm{~d}$ of growth in vitro. For treatment, dishes were gently washed with serum-free growth medium at $37^{\circ} \mathrm{C}$ for $15 \mathrm{~min}$ before addition of reagents.

Neurotrophins (Promega, Madison, WI) were used at a concentration of $200 \mathrm{ng} / \mathrm{ml}$. To determine the ability of the trk receptor bodies to block neurotrophin action, we preincubated trkA-Fc, trkB-Fc, and trkC-Fc receptor bodies $(20 \mu \mathrm{g} / \mathrm{ml})$ with neurotrophins for $15 \mathrm{~min}$. Vehicle, neurotrophins, or neurotrophins preincubated with receptor bodies were applied to $\mathrm{PC} 12$ or cortical cell cultures for $5 \mathrm{~min}$ at $37^{\circ} \mathrm{C}$. After treatment, PC12 cells or cortical cultures were homogenized by sonication for $15 \mathrm{sec}$ in Laemmli sample buffer diluted 1:4 with $1 \mathrm{~mm}$ sodium orthovanadate $(0.0625 \mathrm{M}$ Tris-HCl, $\mathrm{pH} 6.8,10 \%$ glycerol, $1.25 \% \mathrm{w} / \mathrm{v}$ SDS, $5 \% \beta$-mercaptoethanol, $0.00125 \%$ bromphenol blue, and $1 \mathrm{~mm}$ sodium orthovanadate); samples were boiled for $4 \mathrm{~min}$, frozen, lyophilized, and resuspended in $\mathrm{dH}_{2} \mathrm{O}$ to one-fourth of the original volume.

For Western blots, samples were run on 6\% SDS-PAGE gels and transferred to Immobilon-P membranes (Millipore, Bedford, MA). Membranes were fixed with $15 \mathrm{~min}$ of immersion in $25 \%$ methanol/10\% acetic acid, blocked for $1 \mathrm{hr}$ in Blotto buffer (3\% nonfat dry milk and $0.025 \%$ Tween-20 in TBS), and incubated overnight at $4^{\circ} \mathrm{C}$ in pY490 anti-phospho trk antibody (1:1000 in Blotto; New England Biolabs, Beverly, MA). Membranes were subsequently washed three times for 15 min each in Blotto, incubated in peroxidase-conjugated goat anti-rabbit IgG (1:1000 in Blotto; New England Biolabs) for $1 \mathrm{hr}$ at room temperature, washed three times for $15 \mathrm{~min}$ each in Blotto, rinsed in TBS, incubated with a chemiluminescent detection reagent (Lumigen PS-3; Lumigen Technologies) for $1 \mathrm{~min}$, and exposed to film.

After analysis of the phospho trk immunoblots, membranes were incubated in stripping buffer $(0.25 \mathrm{M}$ glycine and $0.05 \%$ Tween $20, \mathrm{pH}$ $2.5)$ at $80^{\circ} \mathrm{C}$ for $2 \mathrm{hr}$, reblocked with Blotto, and processed as described above, except that (1) primary antibody was a rabbit polyclonal antibody directed against the $\mathrm{C}$ terminal of all trks (Trk [C-14]; 1:1000 dilution; Santa Cruz Biotechnology, Tebu, France) and (2) a less-sensitive chemiluminescence detection system was used (ECL; Amersham, Arlington Heights, IL).

Electrode implantation and intraventricular cannulation. Male Sprague Dawley rats (200-300 gm; $n=108)$ were anesthetized with sodium pentobarbital $(60 \mathrm{mg} / \mathrm{kg})$ and placed in a stereotaxic frame. Bipolar electrodes made from teflon-coated stainless steel wire (diameter, 0.01 inch) were implanted into the right basolateral amygdala (from bregma: $-2.8 \mathrm{~mm}$ anteroposterior; $+4.9 \mathrm{~mm}$ lateral; and $-8.6 \mathrm{~mm}$ dorsal) (Paxinos and Watson, 1982). An osmotic minipump (Alzet model 2002; flow rate, $0.5 \mu \mathrm{l} / \mathrm{hr}$; Alza Corporation), aseptically prefilled with either saline, control human IgG (hIgG) $(50 \mu \mathrm{g} / \mathrm{d}$; Jackson ImmunoResearch, West Grove, PA), or trk receptor bodies trkA-Fc, trkB-Fc, or trkC-Fc (5 or 50 $\mu \mathrm{g} / \mathrm{d}$; Regeneron Pharmaceuticals), attached to a cannula via polyethylene tubing, and prewarmed in $0.9 \% \mathrm{NaCl}$ at $37^{\circ} \mathrm{C}$ for $4 \mathrm{hr}$, was placed subcutaneously in the nuchal area. The cannula was implanted stereotaxically with the tip in the right lateral ventricle $(-0.8 \mathrm{~mm}$ anteroposterior; $+1.5 \mathrm{~mm}$ lateral; and $-3.6 \mathrm{~mm}$ dorsal) (Paxinos and Watson, 1982). Cannula and electrode were secured firmly to the skull with dental cement and anchor screws, and a ground wire was attached to one anchor screw. In several preliminary experiments, acute injection of Evans blue dye and postmortem histological examination were performed to verify cannula patency and cannula and electrode placement. Animals were allowed to recover for $4 \mathrm{~d}$ after surgery before initiation of kindling stimulations.

Kindling procedure. Each kindling stimulation consisted of a $60 \mathrm{~Hz} 1$ sec train of $1 \mathrm{msec}$ biphasic rectangular pulses at an amplitude $100 \mu \mathrm{A}$ above the electrographic seizure threshold (EST). The EST was determined by increasing stimulation intensity on the first day of stimulation by $100 \mu \mathrm{A}$ increments at 1 min intervals starting at $100 \mu \mathrm{A}$. Animals were stimulated twice per day for $11 \mathrm{~d}$ (22 total stimulations). Behavioral (seizure class) and electrophysiological [electrographic seizure duration (ESD)] parameters were recorded for each stimulation by an observer blinded to treatment. Behavioral seizure class was scored according to Racine's classification (Racine, 1972): class 0, no behavioral change; class 1 , facial clonus; class 2 , head nodding; class 3 , unilateral forelimb clonus; class 4 , rearing with bilateral forelimb clonus; and class 5 , rearing and falling (loss of postural control). Animals were considered to be fully 
kindled when they exhibited three consecutive class 4 or 5 seizures with a clonic motor component that was $\geq 20 \mathrm{sec}$. Animals that did not reach this kindling criterion within the allotted 22 stimulations (time course of discharge of the osmotic minipump) were assigned the minimum number of stimulations possible as a kindling score (e.g., 24 for a 22 nd stimulation that yielded a first class 4 or 5 seizure).

Histology and exclusion criteria. On the 15 th day after implantation, animals were perfused intracardially with $0.4 \%$ sodium sulfide in $1 \times \mathrm{PBS}$ (5 min) followed by $3 \%$ glutaraldehyde in $\mathrm{H}_{2} \mathrm{O}(10 \mathrm{~min})$. Osmotic minipumps were retrieved, and discharge efficacy was verified by measuring pump residual volume. Brains were cryoprotected in $30 \%$ sucrose, $3 \%$ glutaraldehyde, and $1 \times$ PBS for several days and were frozen in a dry ice and isopentane bath. Fifty micrometer horizontal frozen sections were cut and stored floating in PBS. Sections from each animal (total $n=$ 108) were stained with methyl green-pyronine $Y$ and analyzed by an observer blinded to both treatment status and kindling profile. A commonly encountered difficulty was the occurrence of hydrocephalus with resulting tissue compression and shift of the midline structures; animals exhibiting hydrocephalus $(n=37)$, evidence of infection $(n=4)$, a broken electrode $(n=7)$, or cannula misplacement $(n=2)$ were excluded from analysis. Electrode placements in the animals included in the study $(n=58)$ were verified to be in the amygdala or deep layers of the piriform cortex.

Fc immunohistochemistry. Tissue penetration of either hIgG or trk receptor bodies (trkA-Fc, trkB-Fc, and trkC-Fc) was assessed via immunohistochemistry using an antibody to $\mathrm{hIgG} \mathrm{Fc}_{\gamma}$. Free-floating sections from each animal were treated in $0.3 \% \mathrm{H}_{2} \mathrm{O}_{2}$ in $100 \% \mathrm{MeOH}$ to quench endogenous peroxidase activity (10 min), washed in $1 \times$ PBS (10 min), blocked in $10 \%$ sheep serum in $1 \times \operatorname{PBS}(30 \mathrm{~min})$, treated with 1:500 biotin-conjugated goat anti-human $\operatorname{IgG}\left(\mathrm{Fc}_{\gamma}\right.$ specific; Jackson ImmunoResearch) in $2 \%$ BSA in $1 \times$ PBS $(1 \mathrm{hr})$, washed in $2 \%$ BSA in $1 \times$ PBS (twice for 10 min each), incubated in Vectastain Elite ABC reagent (30 min; Vector Laboratories, Burlingame, CA), washed in 2\% BSA in $1 \times$ PBS (twice for 10 min each), mounted in $1 \times$ PBS, rinsed in $\mathrm{H}_{2} \mathrm{O}$, air dried, and developed in TrueBlue peroxidase substrate (5 min; KPL, Gaithersburg, MD). Each experiment included control sections from noninf used and saline-infused animals as well as sections from animals inf used with hIgG or trk receptor body but not incubated with anti-hIgG. Reactions for all sections were performed in the identical treatment solutions to permit direct comparison of the intensity of immunoreactivity. In all cases, reaction development was stopped before nonspecific immunoreactivity was seen in the control sections.

Quantification of Fc immunoreactivity. Two sections from each animal at equivalent horizontal levels $(-3.10$ and $-4.28 \mathrm{~mm}$ horizontal) (Paxinos and Watson, 1982) were analyzed further. An observer blinded both to treatment and kindling profile scored the intensity of immunoreactivity for each structure in each section on a $0-3$ scale, where $3=$ intensely positive immunoreactivity throughout most or all of the structure, $2=$ moderately positive immunoreactivity throughout a portion of the structure, 1 = barely detectable immunoreactivity in a small part of the structure, and $0=$ no detectable immunoreactivity in the structure. Bilateral structures were assigned separate scores for left and right cerebral hemispheres (e.g., 3 for the right hippocampus and 2 for the left hippocampus). Nissl-stained alternate sections were used to verify the identity of structures. Scores from the left and right of each structure were added for each horizontal level and averaged between levels if the structure appeared in both levels (e.g., hippocampus). Thus, the maximum possible immunoreactivity score would be 6 , although this was never observed because the left side (contralateral to infusion) nearly always was less intensely immunoreactive than was the right (ipsilateral to infusion). All scores fell between 0 and 5. Blinded assessment of a subset (10) of the slides included in this analysis was repeated to verify the reproducibility of this blinded semiquantitative scoring system; in each instance immunoreactivity scores in the hippocampus and striatum were identical to those obtained in the initial assessment.

\section{RESULTS}

\section{Efficacy and specificity of trk receptor bodies}

To establish the efficacy and specificity of the receptor bodies used in this study, a functional assay of their ability to block neurotrophin action was developed. A polyclonal antibody that recognizes trkA, trkB, and trkC receptors that are phosphorylated at tyrosine 490 (Segal et al., 1996) (New England Biolabs) was used to assess the degree of trk receptor activation in response to exogenously applied neurotrophins (Schlessinger and Ulrich, 1992). In PC12 cells, NGF application induces phosphorylation of trkA (Klein et al., 1991). Compared with vehicletreated cultures, NGF-treated PC12 cells showed a robust phospho trk-immunoreactive band at $\sim 140 \mathrm{kDa}$ (Fig. 2A, lanes 1-2). This band is likely to represent trkA based on size, induction by NGF, and comigration with the band seen after stripping the blot and reprobing with a pan trk antibody that recognizes all trk receptors (Fig. 2B, lanes 1-5). Preincubation with a 10-fold molar excess of trkA-Fc, but not of trkB-Fc or trkC-Fc, completely blocked NGF-induced trk phosphorylation (Fig. 2A, lanes 3-5).

Because PC12 cells do not express trkB or trkC receptors, primary cortical cultures were used to assay the efficacy and specificity of trkB-Fc and trkC-Fc. The application of BDNF and NT-3 to cortical cultures results in rapid and robust trk phosphorylation (Knusel et al., 1992). BDNF or NT-3 application to cortical cultures induced a robust phospho trk-immunoreactive band compared with that in vehicle-treated cultures (Fig. 2C, lanes 2,6 vs 1 ), which again comigrated with the major pan trk-immunoreactive band seen after reprobing the membrane (Fig. 2D). These bands are likely to represent trkB and trkC, respectively, based on the specificity of these neurotrophins in neuronal cells (Ip et al., 1993). Preincubation with trkB-Fc, but not with trkA-Fc or trkC-Fc, completely blocked BDNF-induced trk phosphorylation (Fig. 2C, lanes 3-5). Preincubation of NT-3 with receptor bodies yielded a more complex pattern of inhibition; both trkB-Fc and trkC-Fc blocked completely whereas trkA-Fc significantly attenuated NT-3-induced trk phosphorylation (Fig. 2C, lanes 7-9).

\section{Development of kindling}

Administration of trkB-Fc (50 $\mu \mathrm{g} / \mathrm{d}$, i.c.v.) delayed kindling development relative to that either with $\mathrm{hIgG}(50 \mu \mathrm{g} / \mathrm{d}$, i.c.v. $)$ or in saline controls. An example of trkB-Fc-mediated inhibition of kindling development is evident in the behavioral and electrographic response to the 12th kindling stimulation of an hIgGtreated and a trkB-Fc-treated animal (Fig. 3). Although the hIgG-treated control shows a 36 sec electrographic seizure, consisting of $6 \mathrm{sec}$ of limbic seizure and $30 \mathrm{sec}$ of clonic motor seizure, the trkB-Fc-treated animal displays a brief electrographic seizure $(19 \mathrm{sec})$ that was behaviorally less intense ( $9 \mathrm{sec}$ of immobility followed by $10 \mathrm{sec}$ of facial clonus). Such mild seizures were never observed after so many stimulations in control animals.

TrkB-Fc (Fig. 4B; $50 \mu \mathrm{g} /$ d, i.c.v.) inhibited behavioral seizure development as evident in the $18.9 \pm 1.3$ stimulations required to reach the kindled state (defined as three consecutive clonic motor seizures; see Materials and Methods) compared with $12.5 \pm 1.8$ for saline-treated and $12.3 \pm 0.7$ for hIgG-treated animals (Fig. $4 D)$. The inhibitory effect of trkB-Fc was evident throughout kindling development and was not specific to any behavioral seizure class (Fig. 4B). TrkB-Fc-treated animals also required significantly more stimulations to reach the first class 2 seizure $(11.7 \pm 1.5)$ compared with $\mathrm{hIgG}(5.6 \pm 0.6)$ or saline $(6.7 \pm 1.0)$ groups $(p<0.01)$.

The nature of the experimental design led to an underestimate of the magnitude of the inhibitory effects of trkB-Fc when presented as the number of stimulations required to reach the kindled state (Fig. 4D, 18.9 stimulations). Because of the limited duration of the osmotic minipump infusion, the maximum number of stimulations possible during the influence of drug was 22 

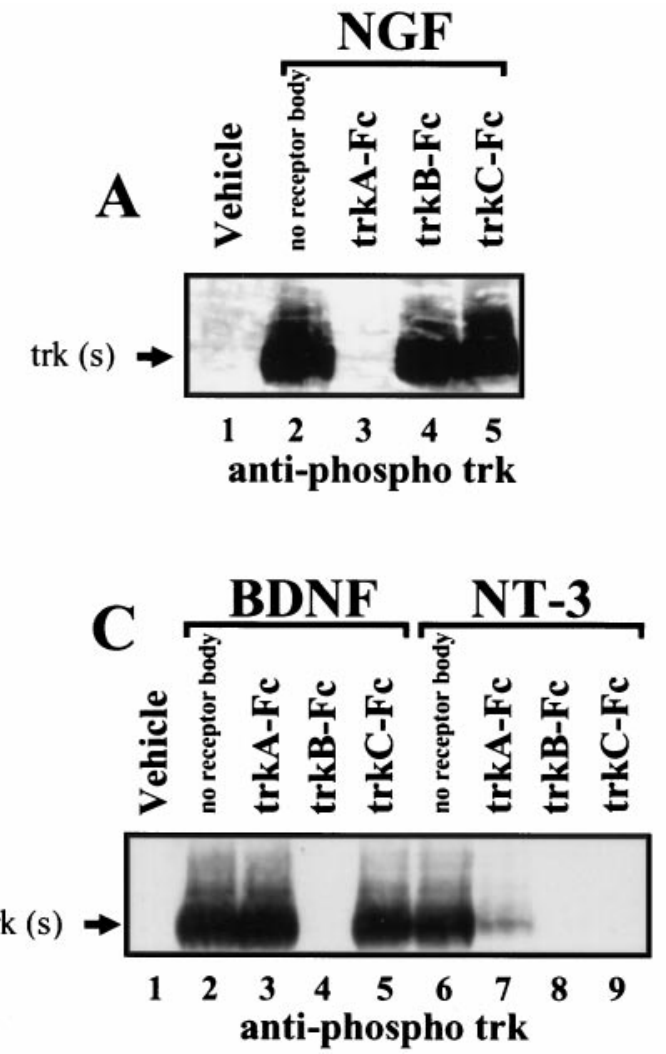

B

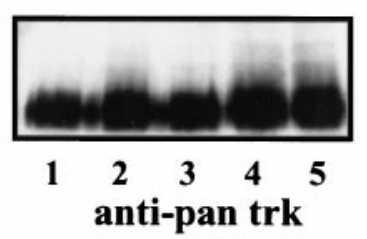

D

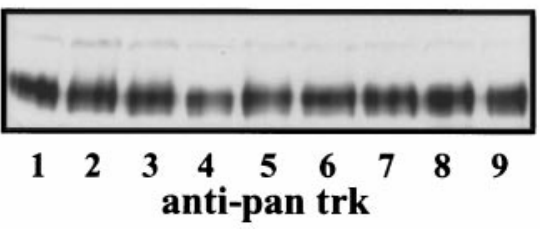

Figure 2. Efficacy and specificity of trk receptor bodies. $A$, Western blot using antiphospho trk antibody performed on PC12 cell extracts from vehicle-treated cultures (lane 1) or cultures treated with NGF (lanes $2-5)$ in the presence or absence of the indicated trk receptor bodies. $B$, Blot shown in $A$ stripped and reprobed with anti-pan trk antibody that labels all trk proteins regardless of phosphorylation state. $C$, Western blot performed on cortical cell extracts from vehicle-treated cultures (lane 1 ) or cultures treated with BDNF (lanes 2-5) or NT-3 (lanes 6-9) in the presence or absence of the indicated trk receptor bodies. $D$, Blot shown in $C$ stripped and reprobed with the anti-pan trk antibody.
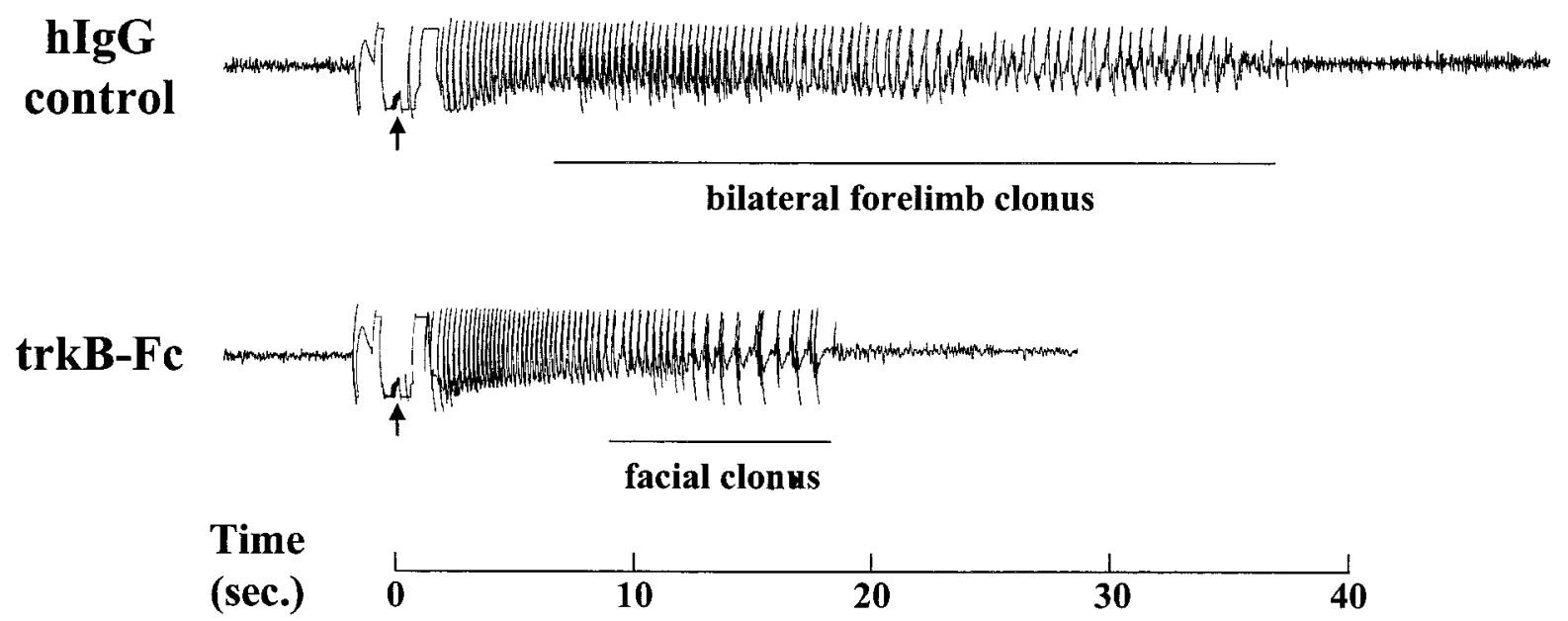

Figure 3. Sample electroencephalograms from seizures in $h I g G$ versus $t r k B-F c$ groups. The 12 th stimulation for each animal is shown. Each arrow marks a stimulation artifact, and the time base is shown at the bottom. Whereas the $h I g G$-treated animal had a 36 sec seizure discharge with a clonic motor component of $30 \mathrm{sec}$ (class 4 seizure), the trkB-Fc-treated animal had only a 19 sec seizure discharge with facial clonus (class 1 seizure). Such a mild seizure on the 12 th stimulation was never seen in the control animals.

(twice daily for $11 \mathrm{~d}$ ). Five out of 14 of the animals in the trkB-Fc group failed to reach the kindled state within the 22 stimulations allotted during discharge of the osmotic minipump and were assigned the minimum number of stimulations possible as a kindling score (e.g., 25 for an animal that never exhibited a class 4 or 5 seizure; see Materials and Methods). By contrast, no animal in any of the other treatment groups failed to reach kindling criterion during the stimulation period.

The inhibitory effects of trkB-Fc on electrographic seizure duration (Fig. $5 B$ ) were subtle by comparison with effects on behavioral seizure class. The cumulative electrographic seizure duration from stimulations 1-10 was lower in the trkB-Fc-treated animals (Fig. 5D, $224 \pm 22 \mathrm{sec}$ ) compared with hIgG-treated animals $(294 \pm 23 \mathrm{sec})$; however, this trend was not significant with the trkB-Fc animals considered as a group ( $p=0.06$ vs $\mathrm{hIgG})$. TrkB-Fc had no effect on electrographic seizure threshold $(328 \pm 35 \mu \mathrm{A})$ compared with the results of saline $(375 \pm 56 \mu \mathrm{A})$ and hIgG $(342 \pm 62 \mu \mathrm{A})$ controls $(p>0.05)$.

A 10 -fold lower dose of trkB-Fc $(5 \mu \mathrm{g} / \mathrm{d})$ did not inhibit behavioral seizure development in that no significant differences 

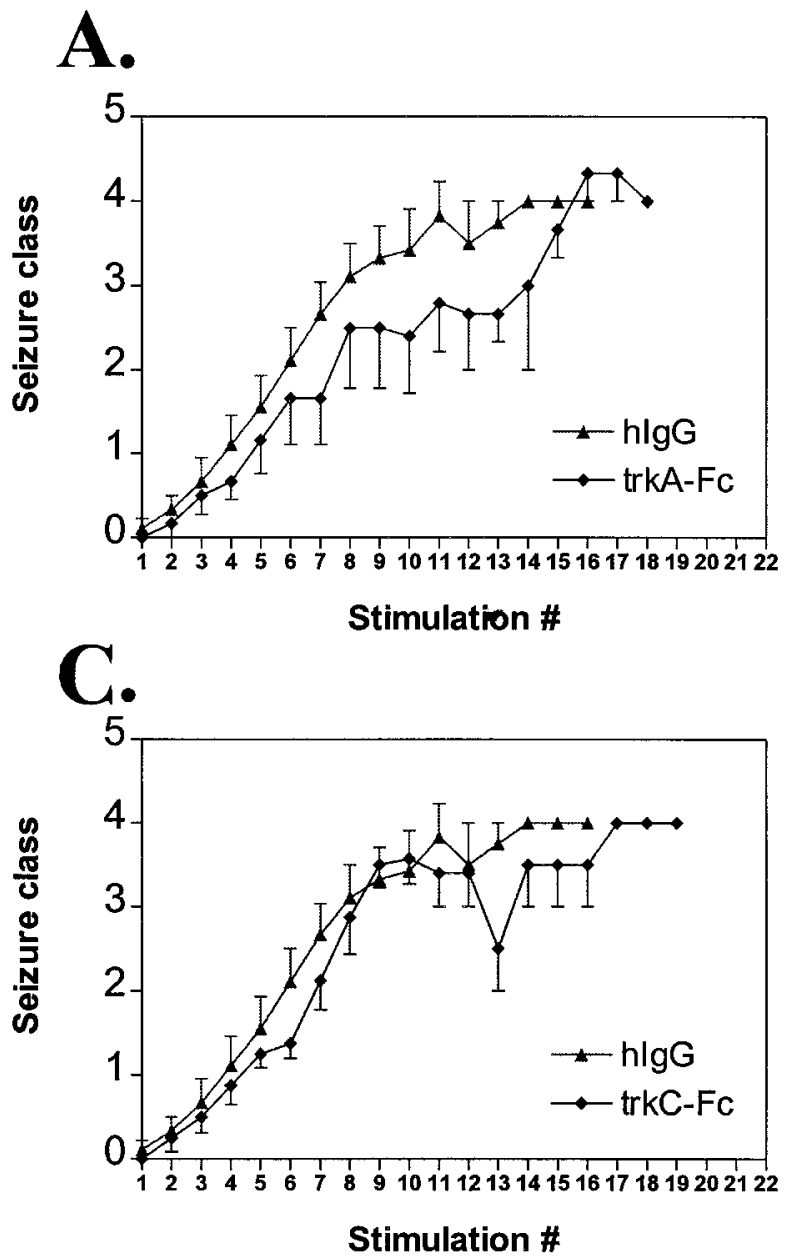

B.

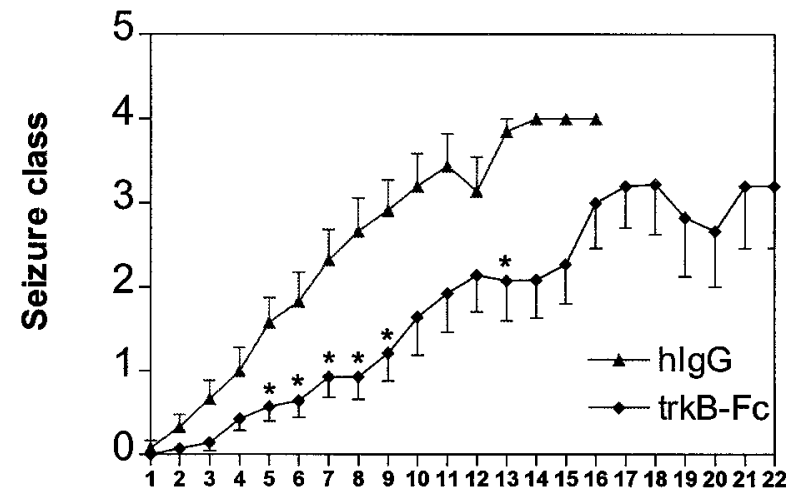

Stimulation \#

D.

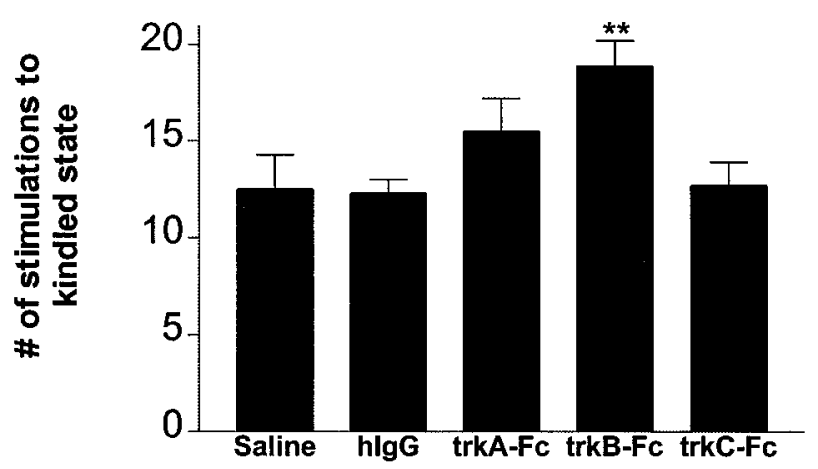

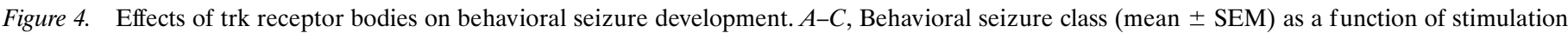

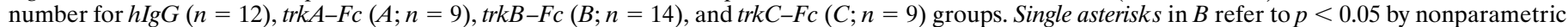

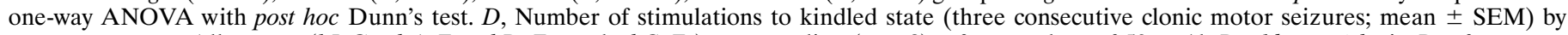

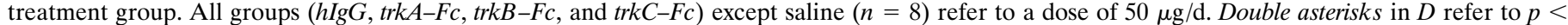
0.01 for $\operatorname{trk} B-F c$ versus $h \operatorname{Ig} G$ by one-way ANOVA with post hoc Bonferroni's test.

were detected among trkB-Fc $(5 \mu \mathrm{g} / \mathrm{d} ; n=6)$, hIgG, or saline groups in the number of stimulations to achieve kindling criterion $(12.0 \pm 0.5$ vs $12.3 \pm 0.7$ and $12.5 \pm 1.8$, respectively), the number of stimulations to the first class 2 seizure $(6.3 \pm 0.5$ vs $5.6 \pm 0.6$ and $6.7 \pm 1.0$, respectively), or the electrographic seizure duration (274 $\pm 30 \mathrm{sec}$ vs $294 \pm 23$ and $338 \pm 43 \mathrm{sec}$, respectively; all $p>0.05$ vs controls).

Administration of hIgG protein itself did not alter kindling development in comparison with that in saline controls. There was no significant difference between the number of stimulations required to reach the kindled state in animals treated with saline intracerebroventricularly (Fig. $4 D, 12.5 \pm 1.8$ ) compared with animals treated with $\mathrm{hIgG}(50 \mu \mathrm{g} / \mathrm{d}$, i.c.v.; $12.3 \pm 0.7 ; p>0.05)$. Nor was there any significant difference in cumulative electrographic seizure duration between hIgG and saline groups (Fig. $5 D ; p>0.05)$. Modest ventricular enlargement was evident in all animals treated with protein $(50 \mu \mathrm{g} / \mathrm{d}$; i.c.v. $)$, but this effect was observed whether the protein was hIgG or any of the trk receptor bodies. The similarity in kindling parameters between the saline and $\mathrm{hIgG}$ controls demonstrates that intracerebroventricular administration of protein $(50 \mu \mathrm{g} / \mathrm{d})$ alone with the associated mod- est ventricular enlargement has no detectable effects on kindling development. In addition, there was no difference in electrographic seizure threshold between $\mathrm{hIgG}$ and saline groups $(342 \pm$ 62 and $375 \pm 56 \mu \mathrm{A}$, respectively; $p>0.05)$.

In contrast to trkB-Fc, neither trkA-Fc nor trkC-Fc significantly delayed kindling development. No significant differences were detected in the number of stimulations required to achieve kindling criterion among animals treated with $\operatorname{trkA}-\mathrm{Fc}(50 \mu \mathrm{g} / \mathrm{d})$, trkC-Fc $(50 \mu \mathrm{g} / \mathrm{d}), \mathrm{hIgG}$, or saline (Fig. $4 A, C, D ; 15.5 \pm 1.7$, $12.7 \pm 1.2,12.3 \pm 0.7$, and $12.5 \pm 1.8$, respectively). Likewise no significant differences were detected in the number of stimulations required to evoke the first class 2 seizure among the four groups $(8.7 \pm 1.6,6.4 \pm 0.5,5.6 \pm 0.6$, and $6.7 \pm 1.0$, respectively; $p>0.05$ vs controls). Similarly, although there was a slight trend toward reduced electrographic seizure duration in trkA-Fc and trkC-Fc compared with $\mathrm{hIgG}$ or saline groups, no significant differences were detected among measures of electrographic seizure duration among the four groups (Fig. 5A,C); trkA-Fc and trkC-Fc did not significantly affect cumulative electrographic seizure duration via stimulation 10 (Fig. $5 D ; p>0.05$ vs controls). In addition, there were no differences in electrographic seizure 


\section{A.}
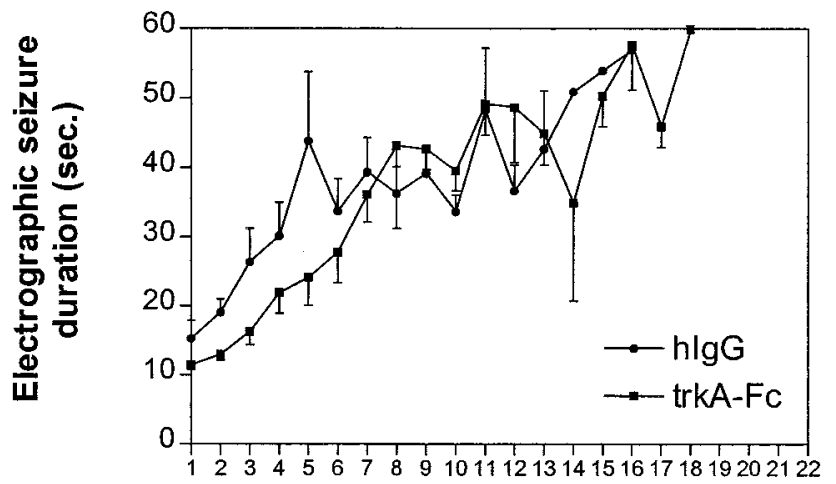

Stimulation \#
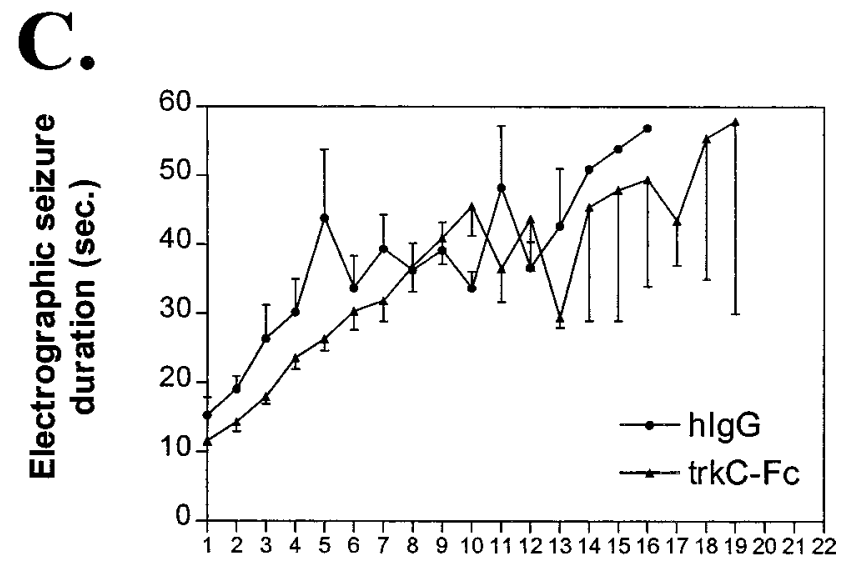

B.

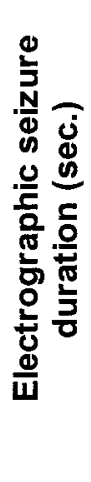

D.

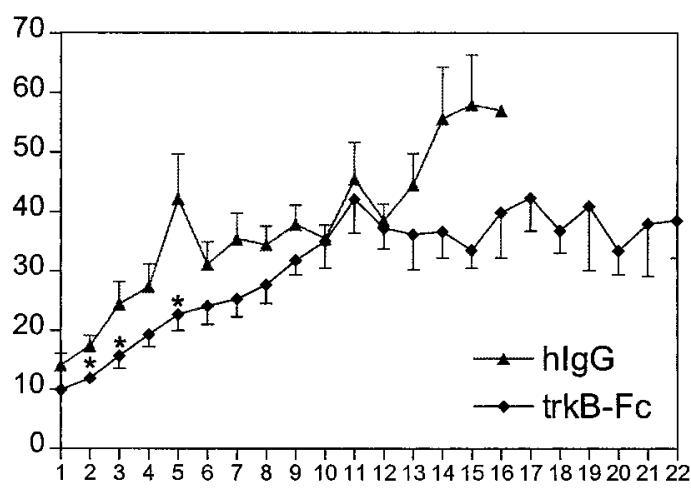

Stimulation \#

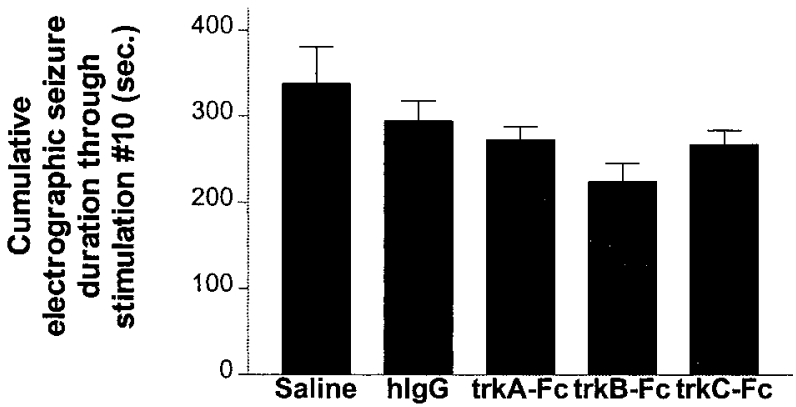

Stimulation \#

Figure 5. Effects of trk receptor bodies on electrographic seizure duration. $A-C$, Electrographic seizure duration (in seconds; mean \pm SEM) as a function of stimulation number for $h \operatorname{Ig} G$, trk $A-F c(A), \operatorname{trk} B-F c(B)$, and trkC-Fc $(C)$ groups. Single asterisks in $B$ refer to $p<0.05$ by nonparametric one-way ANOVA with post hoc Dunn's test. $D$, Cumulative electrographic seizure duration (mean \pm SEM) via kindling stimulation 10 by treatment group. There was no significant difference between groups in cumulative electrographic seizure duration (one-way ANOVA, $p>0.05$ ).

threshold in trkA-Fc $(333 \pm 47 \mu \mathrm{A})$ and trkC-Fc $(289 \pm 35 \mu \mathrm{A})$ groups compared with trkB-Fc $(328 \pm 35 \mu \mathrm{A}), \operatorname{hIgG}(342 \pm 62$ $\mu \mathrm{A})$, or saline $(375 \pm 56 \mu \mathrm{A})$ groups $(p>0.05)$.

\section{Anatomic distribution of infused proteins and relationship to kindling development}

Although the inhibitory effects of trkB-Fc $(50 \mu \mathrm{g} / \mathrm{d})$ on kindling development were clear-cut, there was nonetheless marked variability in the number of stimulations required to achieve kindling criterion within this group (range, 12-25). Because previous investigators found $>20$-fold variation in cerebellar NGF content after continuous intracerebroventricular NGF infusion (Saffran et al., 1989), we hypothesized that the anatomic extent of tissue penetration of trkB-Fc may positively correlate with inhibition of kindling development in individual animals. To address this issue, we examined the distribution of trkB-Fc and other infused proteins using immunohistochemistry with an antibody specific for the $\mathrm{Fc}$ region of human $\mathrm{IgG}$, a domain present in all the inf used proteins studied (but not in the host rat brain).

As suspected, considerable variability was detected in the intensity and distribution of Fc immunoreactivity among individual animals. The ventricular system was immunoreactive in all animals infused with protein at $50 \mu \mathrm{g} / \mathrm{d}$ (whether hIgG, trkA-Fc, $\operatorname{trkB}-\mathrm{Fc}$, or trkC-Fc). This immunoreactivity was visible in the ependyma of the right and left lateral ventricles (although the left was usually less intensely immunoreactive than the right), in the ependyma of the third ventricle and the aqueduct of Sylvius, and in the pia mater surrounding the brain (Fig. 6B; data not shown). Parenchymal tissue immunoreactivity was quite variable in individual animals, but the most commonly positive structures were the hippocampus, striatum, septum, corpus callosum, and subcortical white matter. This is consistent with the proximity of these structures to the cannula tip in the lateral ventricle. In all of these structures, immunoreactivity was nearly always more intense on the right (infused) side compared with the left and was more intense closer to the cannula site. In addition, a steep gradient of immunoreactivity from ependyma to parenchyma was evident (Fig. 6B), consistent with previous studies and theoretical predictions (Saffran et al., 1989; Pardridge, 1991). In contrast, no Fc immunoreactivity was detected in the amygdala or cortical areas (data not shown). Marked variation in intensity of immunoreactivity was evident among individual animals (see paragraph below). Specificity controls included analysis of saline-treated animals and omission of the anti-human IgG Fc antibody. Parenchymal immunoreactivity was never observed in salinetreated animals, and omission of the anti-human IgG Fc antibody always abrogated all immunoreactivity (data not shown). 


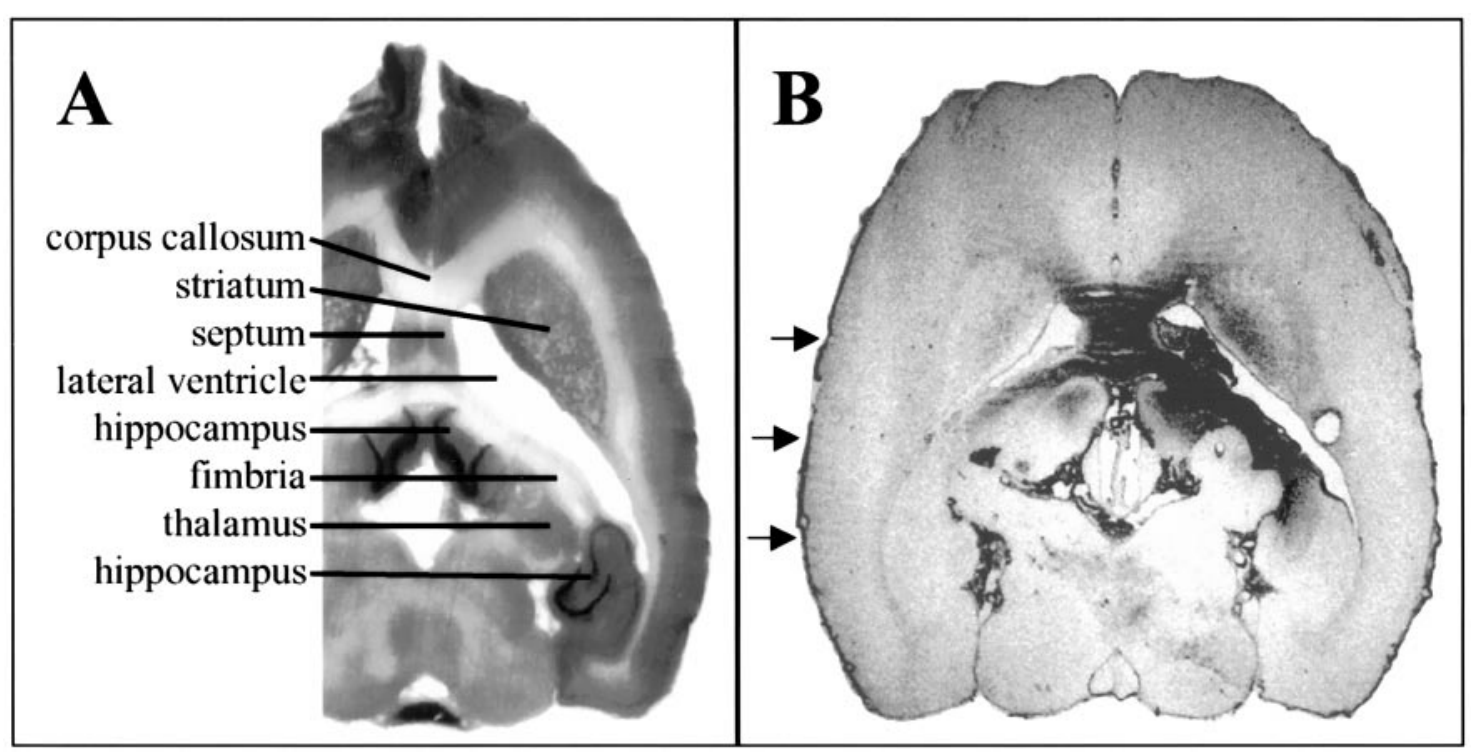

Figure 6. Immunohistochemistry for anti-hIgG $\mathrm{Fc}_{\gamma} \cdot A$, Portion of Nissl-stained horizontal section at approximate level of $B$. Selected structures are labeled. $B$, Horizontal section from an animal inf used with hIgG showing the typical distribution of immunoreactivity (right side, infusion site). In this animal, note the immunoreactivity in the septum bilaterally, the corpus callosum, the right striatum, the right hippocampus, and the fimbria and light immunoreactivity in the left hippocampus and the fimbria. Arrows mark the immunoreactivity in pia surrounding the brain.

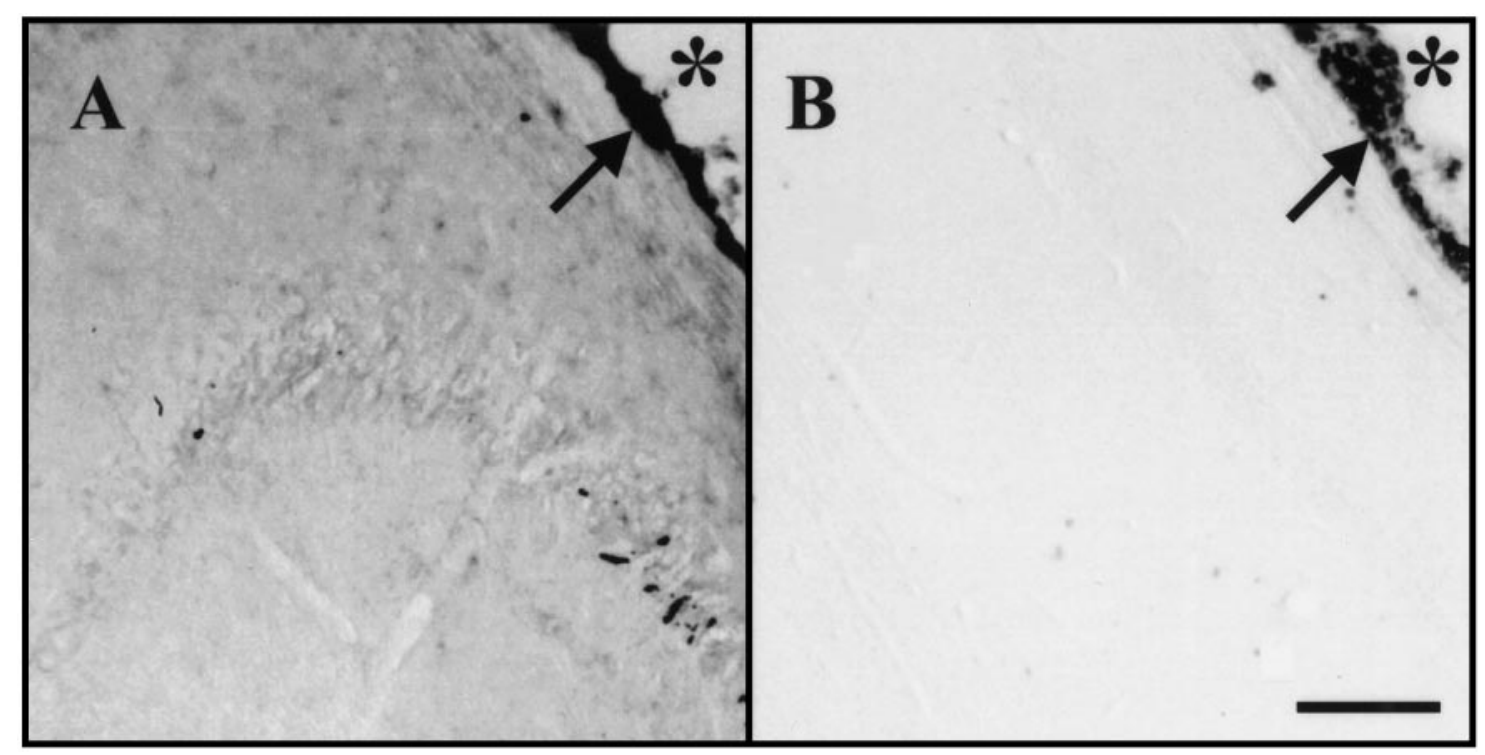

Figure 7. Presence of $\mathrm{Fc}$ immunoreactivity in the hippocampus correlates with the effect of trkB-Fc on kindling development. $A$, Right hippocampal section of a trkB-Fc-treated animal with marked inhibition of kindling development (did not reach the kindled state in 22 stimulations). Ependymal immunoreactivity is visible (arrow) lining the right lateral ventricle (asterisk), and significant hippocampal parenchymal immunoreactivity is evident. $B$, Right hippocampal section of the trkB-Fc-treated animal in which there was the least effect on kindling development (12 stimulations required to reach the kindled state). Ependymal immunoreactivity is visible (arrow) lining the right lateral ventricle (asterisk), but no hippocampal parenchymal immunoreactivity is evident. Scale bar: $A, B, 200 \mu \mathrm{m}$.

The variability both in intensity and anatomic distribution of the immunoreactivity provided the opportunity to ask whether some particular anatomic pattern correlated with inhibition of kindling development. The relative immunoreactivity of the two most commonly immunoreactive structures, the hippocampus and striatum, was assessed with a semiquantitative scale (see Materials and Methods), and the results of kindling development were compared with the immunoreactivity pattern in each animal. Within the trkB-Fc group, the degree of hippocampal immunoreactivity significantly correlated with the magnitude of inhibition of kindling development in individual animals (see Fig. 8B, left; Spearman $p<0.01$ ). Figure $7 A$ shows the right hippocampal immunoreactivity of a trkB-Fc-treated animal with a marked retardation of kindling development (did not reach kindling criterion within 22 allotted stimulations); robust parenchymal immunoreactivity is evident. In contrast, Figure $7 B$ shows the right hippocampal immunoreactivity of the trkB-Fc-treated animal that showed the least inhibition of kindling development (12 stimulations to the kindled state); immunoreactivity of the ependyma but not the parenchyma is evident. In contrast to the 


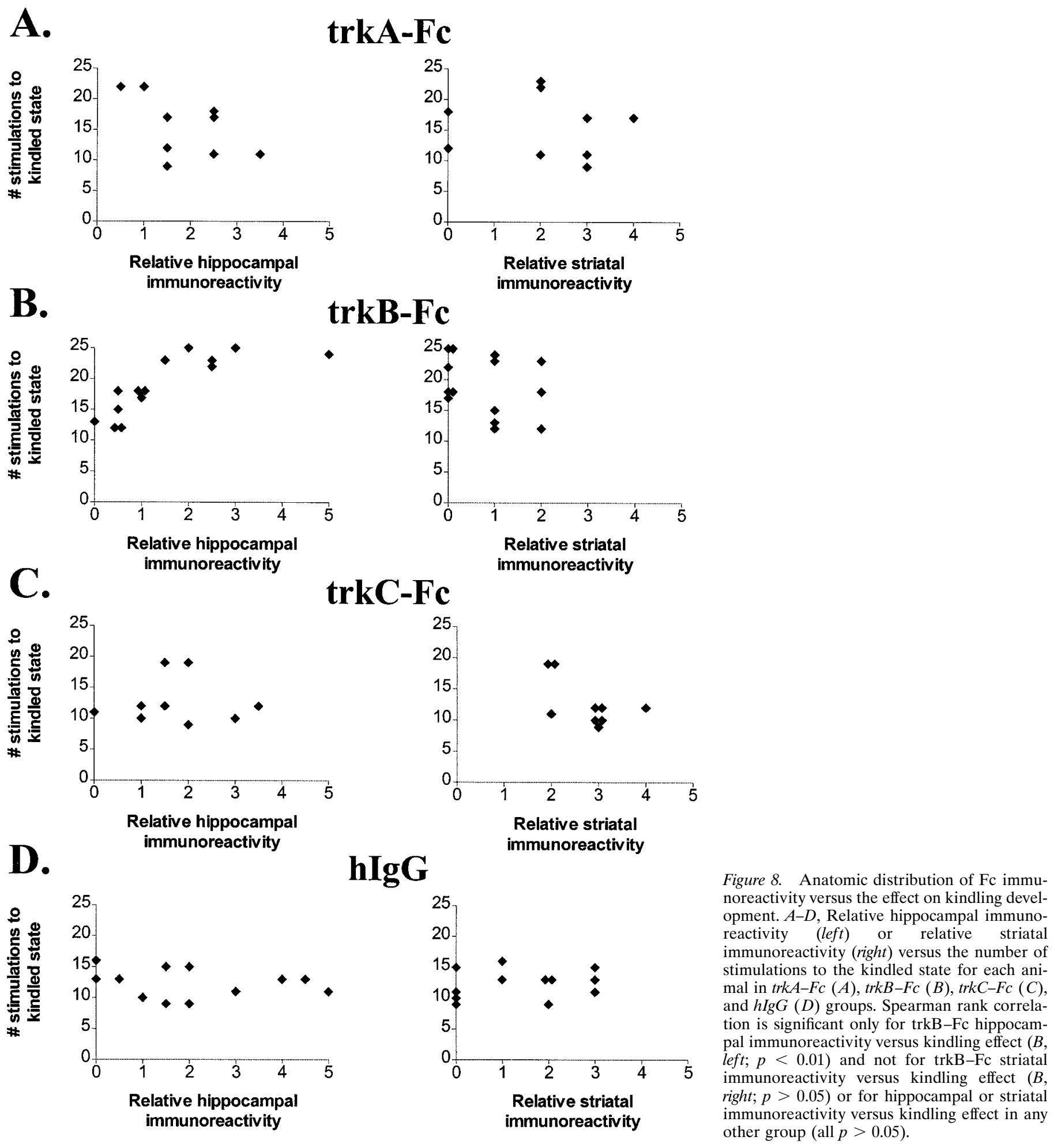

positive correlation identified with hippocampal immunoreactivity, striatal immunoreactivity in the trkB-Fc group did not correlate with the magnitude of kindling inhibition (Fig. 8B, right; Spearman $p>0.05$ ). Moreover, two animals excluded from the trkB-Fc group because the cannula tip was misplaced in the striatum showed intense striatal immunoreactivity and no inhibition of kindling development, providing further evidence that penetration of trkB-Fc into the striatum does not seem to be responsible for trkB-Fc-mediated inhibition of kindling develop- ment. Immunoreactivity was often detected in both the septum and corpus callosum, yet the degree of immunoreactivity in these structures did not correlate with the magnitude of kindling inhibition (both Spearman $p>0.05$ ).

To assess further the effect of hippocampal trkB-Fc on kindling development, animals with the most intense hippocampal immunoreactivity [termed $\operatorname{trkB}(+) ; n=6$ ] were arbitrarily separated from the animals with the least hippocampal immunoreactivity $[\operatorname{trkB}(-) ; n=8]$ for additional analyses. Behavioral 


\section{A.}

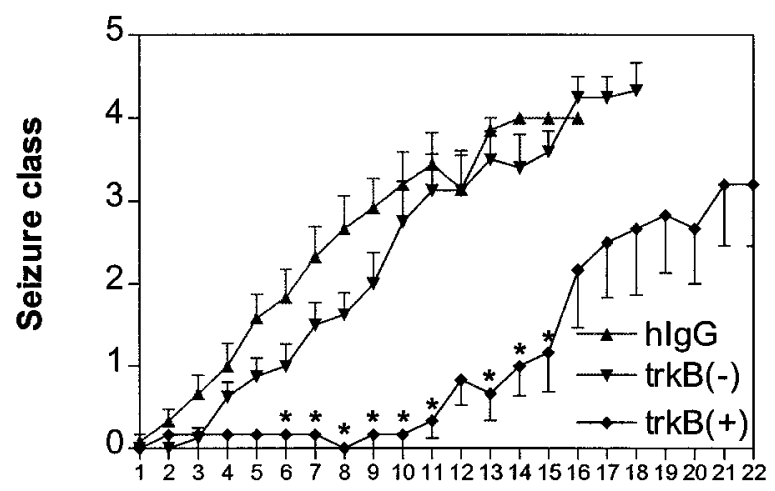

Stimulation \#

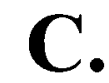

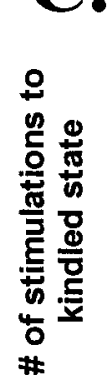

B.

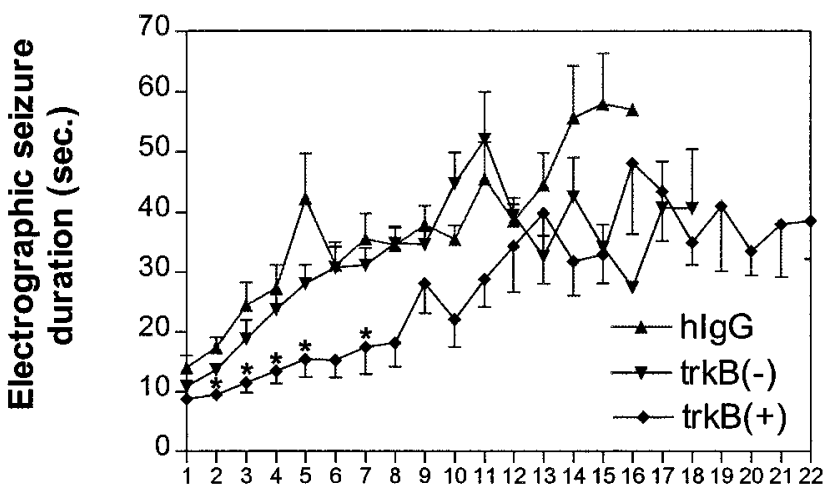

Stimulation \#
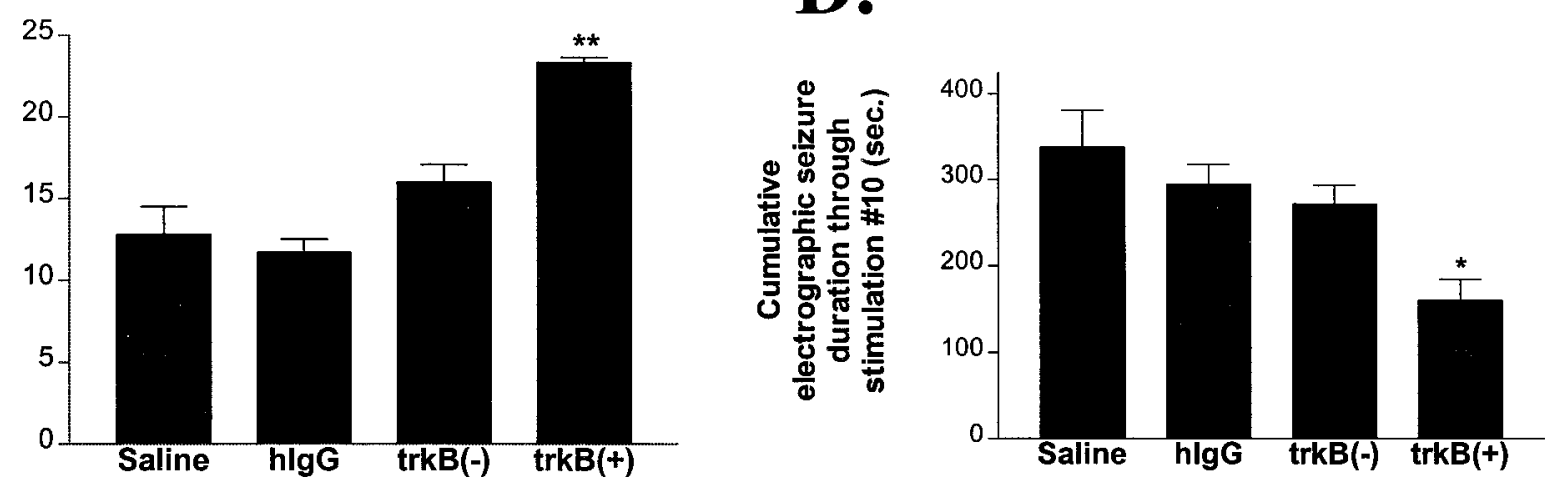

Figure 9. Effect of hippocampal immunoreactivity on kindling parameters within the trkB-Fc group when the original trkB-Fc group $(n=14)$ is separated into intensely immunoreactive $[\operatorname{trk} B(+) ; n=6]$ versus poorly immunoreactive $[\operatorname{trk} B(-) ; n=8]$ animals. $A$, Behavioral seizure class (mean \pm SEM) by stimulation number. Single asterisks refer to $p<0.05$ versus $h \operatorname{Ig} G$ by nonparametric one-way ANOVA with post hoc Dunn's test. $B$, Electrographic seizure duration (mean \pm SEM) by stimulation number. $C$, Number of stimulations to the kindled state (mean \pm SEM) by group. $D$, Cumulative electrographic seizure duration (mean \pm SEM) via stimulation 10 by group. Single and double asterisks in $B-D$ refer to $p<0.05$ and $p<$ 0.01 , respectively, for $\operatorname{trk} B(+)$ versus $h \operatorname{Ig} G$ by one-way ANOVA with post hoc Bonferroni's test.

seizure development was similar in the $\operatorname{trkB}(-)$ and control groups, yet marked inhibition was evident in the $\operatorname{trkB}(+)$ group (Fig. 9A). Similar findings were evident with respect to electrographic seizure duration (Fig. 9B), number of stimulations to kindling (Fig. 9C), and cumulative ESD via stimulation 10 (Fig. $9 D)$. Interestingly, the reduction in ESD in the $\operatorname{trkB}(+)$ group was significant compared with controls $[\operatorname{trkB}(+), 160 \pm 24 \mathrm{sec} ; \mathrm{hIgG}$, $294 \pm 23 \mathrm{sec} ; p<0.05$ vs hIgG], unlike the trkB-Fc group considered as a whole (Fig. $5 D ; p=0.06$ vs hIgG). All animals treated with low-dose trkB-Fc $(5 \mu \mathrm{g} / \mathrm{d})$ showed very poor to no parenchymal immunoreactivity (data not shown) and no inhibitory effect on kindling development (see above).

In contrast to the distinctions noted between the $\operatorname{trkB}(+)$ and $\operatorname{trkB}(-)$ groups, there was no correlation between the extent of immunoreactivity of any structure and the inhibition of kindling development in any of the other groups (Fig. $8 A, C, D$ ). Separation of trkA-Fc and trkC-Fc groups into subgroups with semiquantitative immunoreactivity measures equivalent to $\operatorname{trkB}(+)$ and $\operatorname{trkB}(-)$ groups revealed no correlation between immunoreactivity in any structure and kindling development, even in intensely stained trkA-Fc and trkC-Fc animals (data not shown). Importantly, the distribution and extent of immunoreactivity exhibited similar patterns among the human $\mathrm{IgG}$ and trkA-Fc, trkB-Fc, and trkC-Fc groups, and no significant differences were noted (nonparametric one-way ANOVA, hippocampal or striatal immunoreactivity vs group, $p>0.05$ ) (Fig. 8).

\section{DISCUSSION}

Two principal findings emerge from this work. First, intraventricular administration of trkB-Fc, but not trkA-Fc or trkC-Fc, significantly delays kindling development. This effect is manifest as a reduction in behavioral seizure intensity during kindling development. Second, the degree of penetration of trkB-Fc into the hippocampus, but not the striatum, septum, or other structures, correlates with the magnitude of inhibition of kindling development.

\section{Mechanism of trk-Fc reagents}

Our in vitro experiments (Fig. 2) demonstrate the efficacy of the trk receptor body reagents at blocking a biological endpoint (trk receptor phosphorylation) with expected specificity. In particular, NGF-induced trk phosphorylation was specifically blocked by trkA-Fc, BDNF-induced trk phosphorylation was specifically blocked by trkB-Fc, and NT-3-induced trk phosphorylation was blocked to a variable extent by all receptor bodies. These results are consistent with the known binding specificities of trk receptors and the trk-Fc molecules; that is, trkA-Fc binds NGF, 
trkB-Fc binds BDNF and NT-4, and trkA-Fc, trkB-Fc, and trkC-Fc to varying degrees all bind NT-3 (Shelton et al., 1995).

In our view, the most plausible mechanism of action of trkB-Fc in inhibiting kindling development is sequestration of the endogenous ligand(s) of trkB. Circumstantial evidence favors BDNF over NT-3 and NT-4 as the trkB ligand promoting kindling development. First, although in our in vitro studies trkB-Fc blocked NT-3-induced trk phosphorylation, the lack of effect of infused trkC-Fc on kindling development argues against a role for NT-3. Second, there are much higher levels of BDNF mRNA than of NT-4 mRNA in the adult rat brain (Timmusk et al., 1993). Third, the highest concentration of BDNF protein in the adult brain is in the hippocampus (Nawa et al., 1995; Elmer et al., 1996), the sole anatomic site in which trkB-Fc immunoreactivity correlates with inhibition of kindling development. Fourth, the expression of both BDNF mRNA and protein is markedly increased in the hippocampus by seizure activity (Ernfors et al., 1991; Gall et al., 1991; Isackson et al., 1991; Dugich-Djordjevic et al., 1992a,b; Bengzon et al., 1993; Humpel et al., 1993; Nawa et al., 1995; Elmer et al., 1996; Sato et al., 1996). In contrast, NT-4 mRNA is not detectable in the hippocampus by in situ hybridization and is not increased by seizure activity (Timmusk et al., 1993; Mudo et al., 1996).

\section{Advantages and disadvantages of the present approach}

The strengths of the present approach include the use of reagents whose efficacy and selectivity for inhibiting neurotrophins have been carefully characterized (Fig. 2). The availability of reagents that bind each of the neurotrophins with defined selectivity permits comparing the relative contribution of distinct neurotrophins and neurotrophin receptors in this model. Also, the use of these reagents de novo in the mature brain obviates potential confounding variables of developmental consequences of disrupting neurotrophin signaling.

Limited accessibility of the trk-Fc reagents to their cognate neurotrophins in vivo is a weakness of the present approach. That is, the present approach requires the continuous infusion of a large protein into the lateral ventricle from which the protein must traverse the ependymal lining and diffuse through the complex tortuosities of the extracellular space and potentially penetrate specializations in this matrix to interact with and bind the desired neurotrophin. Substantial variability was detected in the magnitude and anatomic distribution of trk-Fcs among individual animals as evidenced by Fc immunohistochemistry. In addition to the variability inherent in the present approach, we also observed a limited degree of parenchymal penetration of the intracerebroventricular-administered proteins. Access of trk$\mathrm{B}-\mathrm{Fc}$ to the hippocampus ipsilateral to the cannula was greater as evident in increased immunoreactivity in comparison with that in the contralateral hippocampus; thus, sequestration of trkB ligand(s) was almost certainly far more limited in the hippocampus contralateral to the stimulating electrode and infusion cannula. There are likely to be other brain areas in which no sequestration of trkB ligands occurred because of insufficient penetration. Despite the limited degree of penetration, robust inhibitory effects of trkB-Fc in animals with relatively intense Fc immunoreactivity in the hippocampus were nonetheless detected, suggesting that efficient sequestration of trkB ligands throughout the forebrain might more profoundly inhibit or even prevent development of kindling altogether.

A second limitation of the present experimental paradigm is that it does not distinguish whether trkB-Fc dampened seizure expression during the development of kindling or dampened formation of the hyperexcitable state of kindling. That is, to assess whether inf usion of trkB-Fc actually inhibited mechanisms underlying formation of the hyperexcitable state, we would need to assess the response to an additional stimulation after complete washout of the receptor body reagents.

\section{Comparison with previous studies}

Our findings are consistent with other studies suggesting the importance of trkB signaling in kindling development. In particular, Kokaia et al. (1995) reported a greater than twofold reduction in the rate of kindling development in $\mathrm{BDNF}+/-$ mice compared with wild-type littermates. Both basal and seizureinduced levels of BDNF mRNA were lower in the BDNF+/compared with wild-type mice, consistent with the idea that reduced trkB receptor activation in the $\mathrm{BDNF}+/-$ mice contributed to the inhibition of kindling development. The twofold reduction in kindling rate in these animals is striking given that there was presumably some reduction but not elimination of trkB receptor signaling.

Other investigators have examined the effects of infusion of BDNF on kindling development. In apparent conflict with our current findings, chronic intrahippocampal infusion of BDNF inhibits hippocampal kindling development and reduces electrographic seizure duration (Larmet et al., 1995; Reibel et al., 1996). In addition, intracerebroventricular administration of BDNF inhibits amygdala kindling development (Osehobo et al., 1996). However, it seems unlikely that these methods of administering BDNF replicate the spatiotemporal pattern of endogenously released BDNF. Furthermore, prolonged exposure to increased concentrations of BDNF suppresses trkB receptor responsiveness and reduces trkB mRNA and protein levels in vitro (Frank et al., 1996); likewise, a 6 d infusion of BDNF into the adult hippocampus in vivo decreased levels of full-length trkB receptor by $80 \%$ (Frank et al., 1996). If the chronic infusion of BDNF in these kindling studies also led to reduced trkB responsiveness to both exogenous and endogenous BDNF, then the reduced rate of kindling development observed is consistent with our present findings and those of BDNF heterozygotes (Kokaia et al., 1995) in implicating trkB receptor activation in kindling development. Although this interpretation of BDNF infusions seems plausible, whether or how infusion of trk receptor body reagents in the current experiments also regulate endogenous trk receptors is unknown.

The lack of effect of infused trkA-Fc suggests that neither NGF nor trkA nor p75 contributes to kindling development. The ability of NGF to activate p75 (Carter et al., 1996) and the presence of NGF and p75 in the hippocampus (Dougherty and Milner, 1997; Lee et al., 1998), together with increased expression of NGF mRNA after kindling stimulation (Ernfors et al., 1991), raise the possibility that activation of p75 might occur during kindling development. Indeed, kainate-induced seizure activity results in the activation of $\mathrm{NF}-\kappa \mathrm{B}$, a target of p75 signaling (Rong and Baudry, 1996). However, the lack of efficacy of trkA-Fc, even in the subset of animals with intense immunoreactivity in the hippocampus, fails to implicate p75 or trkA in kindling development. This conclusion conflicts with previous studies in which intraventricular infusion of NGF antisera reduced the rate of kindling development in rats by 50-100\% (Funabashi et al., 1988; Van der Zee et al., 1995). Likewise, infusion of a peptide mimic of NGF designed to prevent binding to trkA partially inhibited 
kindling development (Rashid et al., 1995). However, the specificity of these reagents to NGF was uncertain. That is, the antisera in these studies were raised against the entire NGF molecule; because neurotrophin family members share $\sim 50 \%$ sequence identity, such antisera likely contained antibodies against other neurotrophins including BDNF. Indeed, the NGF antisera and peptides were shown to cross-react to some extent with BDNF and NT-3 in in vitro assays (Rashid et al., 1995; Van der Zee et al., 1995), yet these cross-reacting antibodies were not removed by preabsorption with BDNF before use in vivo. Because there is a nonsignificant trend toward kindling inhibition in the trkA-Fc group, it is conceivable that a higher dose of trkA-Fc in the present study may have inhibited the rate of kindling development.

The lack of effect of trkC-Fc argues against the contribution of either NT-3 or trkC to kindling development. This result contrasts with a reduced rate of kindling development reported in NT-3+/- mice (Elmer et al., 1997). One explanation for these divergent findings might be the developmental consequences of reduced levels of NT-3 protein in the NT-3+/- mice. The authors also found altered seizure-induced BDNF, trkB, and trkC gene expression in the NT-3+/- mice, so it is possible that the observed effects were an indirect consequence of the reduction in NT-3. To our knowledge, there are no reports examining the effects of intraventricular infusion of anti-NT-3 antibodies.

One potential explanation for the lack of effect of trkA-Fc or trkC-Fc on kindling development could be that trkA-Fc and trkC-Fc have reduced stability compared with trkB-Fc. However, using a two-site ELISA technique, Cabelli et al. (1997) have shown recently that trkA-Fc and trkB-Fc have similar in vivo stability. Furthermore, the low proportion of partially degraded relative to intact trk-Fcs after osmotic minipump infusion supports the validity of using Fc immunohistochemistry to assess the spatial distribution of the intact receptor body (Cabelli et al., 1997). Thus, at least for trkA-Fc, no increased tissue breakdown relative to trkB-Fc is evident. Combined with the overlapping degree of parenchymal penetration assessed by Fc immunohistochemistry, these findings suggest that differences in tissue breakdown do not contribute to the lack of effect of trkA-Fc and trkC-Fc on kindling development.

\section{TrkB receptor activation and kindling development: potential mechanisms}

How might activation of trkB contribute to kindling development? Possible mechanisms include effects on cell survival, neurite outgrowth, and neuronal excitability. For example, it is possible that BDNF is a survival factor for adult hippocampal neurons and that intracerebroventricular infusion of trkB-Fc results in hippocampal cell death, thereby inhibiting kindling development. This mechanism seems unlikely for several reasons. First, it is not clear whether BDNF is necessary for the survival of adult hippocampal neurons. Although recent studies show increased cell death in the CNS of early postnatal BDNF-/- and trkB-/- mice (Alcantara et al., 1997; Schwartz et al., 1997), no overt differences in hippocampal morphology were detected in BDNF heterozygotes despite marked inhibition of kindling development (Kokaia et al., 1995). Second, there was no overt hippocampal cell death in Nissl-stained alternate sections from any of the trkB-Fc-infused animals (data not shown). Third, essentially total destruction of the dentate granule cells induced by microinjection of colchicine was associated with an inhibition of kindling development equivalent to that observed with trk-
$\mathrm{B}-\mathrm{Fc}$ in the present study; partial destruction of the granule cells was associated with lesser degrees of inhibition but was nonetheless readily detected by nonquantitative histological analysis (Dasheiff and McNamara, 1982). Although destruction of a subpopulation of neurons cannot be excluded, the lack of overt cell death in the trkB-Fc-treated animals, together with results of lesion studies, argues against hippocampal neuronal death as the mechanism of trkB-Fc-induced inhibition of kindling development.

Alternatively, the known morphoregulatory effects of neurotrophins during development (leading to formation of appropriately matched functional circuitry) (Purves, 1988, 1994) raise the possibility that seizure-induced expression of neurotrophins and their receptors may effect long-term changes in a given neuronal ensemble via induction of axonal sprouting and new synapse formation. For example, neurotrophins enhance axonal branching in cultures of hippocampal neurons (Patel and McNamara, 1995; Lowenstein and Arsenault, 1996), and evidence that activityinduced neurotrophin expression may modulate axonal sprouting in vivo comes from inhibition of normal ocular dominance column formation by neurotrophin infusion (Maffei et al., 1992; Cabelli et al., 1995) or trkB-Fc infusion (Cabelli et al., 1997). Activitymediated dendritic modifications induced by neurotrophins may be equally important (McAllister et al., 1995, 1996a,b). Alternatively, BDNF may directly regulate synaptic innervation density in the CNS (Causing et al., 1997). The most prominent synaptic reorganization that occurs in the epileptic brain is the axonal sprouting of dentate granule cell mossy fibers (Sutula et al., 1988). Interestingly, mossy fiber sprouting was increased in BDNF+/compared with $\mathrm{BDNF}+/+$ mice despite the inhibition of kindling development in these mutants (Kokaia et al., 1995). In addition, bath-applied trkB-Fc failed to inhibit kainate-induced mossy fiber sprouting in hippocampal explant cultures (Routbort et al., 1997). Although other unrecognized synaptic reorganizations might be affected by trkB-Fc, inhibition of mossy fiber sprouting is unlikely to be the mechanism by which trkB-Fc inhibits kindling development.

Instead, we suspect that the most likely mechanism by which trkB receptor activation contributes to kindling development is to increase neuronal excitability via regulation of synaptic transmission. BDNF is known to enhance excitatory synaptic transmission (Lohof et al., 1993; Kang and Schuman, 1995; Levine et al., 1995; Stoop and Poo, 1996) and reduce inhibitory synaptic transmission (Tanaka et al., 1997). A critical level of BDNF/trkB activation appears to be vital for modulation of synaptic efficacy; hippocampal slices from BDNF knock-out animals exhibit impaired longterm potentiation (LTP) induction (Korte et al., 1995, 1996; Patterson et al., 1996), and pretreatment of adult hippocampal slices with trkB-Fc reduces LTP (Figurov et al., 1996). Interestingly, acute application of exogenous BDNF to hippocampal slices appears to enhance preferentially the efficacy of the excitatory mossy fiber synapse onto CA3 pyramidal cells (Scharfman, 1997). These results coincide with the observation of increased excitability of CA3 pyramidal cells in kindled animals as detected by increased epileptiform bursting induced by elevated $\left[\mathrm{K}^{+}\right]_{\mathrm{o}}$ in isolated hippocampal slices (King et al., 1985). Although it seems likely that trkB activation occurs at multiple synaptic stations in the limbic system and thus promotes kindling development, the pivotal role of the CA3 pyramidal cells in promoting epileptiform activity in the hippocampus suggests that this may be one site of BDNF action. The fact that constitutive and seizure-induced BDNF immunoreactivity within the hippocampus is most intense 
in the mossy fiber pathway (Conner et al., 1997; Yan et al., 1997) is consistent with this idea. Thus, trkB-Fc may act to inhibit kindling development at least partially via sequestration of BDNF in the mossy fiber-CA3 system and thereby to limit CA3 pyramidal cell excitability. Determining the locus of trkB receptor activation after seizure could conceivably delineate a "functional anatomy" of specific synaptic locations contributing to kindling development.

In summary, we have demonstrated that intraventricular administration of trkB but not trkA or trkC receptor body impairs kindling development in the rat. These results implicate trkB receptors in this particular form of activity-dependent plasticity of the mature brain. It will be interesting to examine whether, where, and when trkB receptor activation occurs during kindling development and to determine to what extent trkB receptors are involved in other forms of adult plasticity, such as learning and memory.

\section{REFERENCES}

Alcantara S, Frisen J, del Rio JA, Soriano E, Barbacid M, Silos-Santiago I (1997) TrkB signalling is required for postnatal survival of CNS neurons and protects hippocampal and motor neurons from axotomyinduced cell death. J Neurosci 17:3623-3633.

Bengzon J, Soderstrom S, Kokaia Z, Kokaia M, Ernfors P, Persson H, Ebendal T, Lindvall O (1992) Widespread increase of nerve growth factor protein in the rat forebrain after kindling-induced seizures. Brain Res 587:338-342.

Bengzon J, Kokaia Z, Ernfors P, Kokaia M, Leanza G, Nilsson OG, Persson H, Lindvall O (1993) Regulation of neurotrophin and trkA, trkB and trkC tyrosine kinase receptor messenger RNA expression in kindling. Neuroscience 53:433-446.

Blochl A, Thoenen H (1995) Characterization of nerve growth factor (NGF) release from hippocampal neurons: evidence for a constitutive and an unconventional sodium-dependent regulated pathway. Eur J Neurosci 7:1220-1228.

Bugra K, Pollard H, Charton G, Moreau J, Ben-Ari Y, Khrestchatisky M (1994) aFGF, bFGF and flg mRNAs show distinct patterns of induction in the hippocampus following kainate-induced seizures. Eur J Neurosci 6:58-66.

Cabelli RJ, Hohn A, Shatz CJ (1995) Inhibition of ocular dominance column formation by infusion of NT-4/5 or BDNF. Science 267:1662-1666.

Cabelli RJ, Shelton DL, Segal RA, Shatz CJ (1997) Blockade of endogenous ligands of trkB inhibits formation of ocular dominance columns. Neuron 19:63-76.

Carter BD, Kaltschmidt C, Kaltschmidt B, Offenhauser N, Bohmmatthaei R, Baeuerle PA, Barde YA (1996) Selective activation of NF-kappa-B by nerve growth factor through the neurotrophin receptor $\mathrm{p} 75$. Science 272:542-545.

Causing CG, Gloster A, Aloyz R, Bamji SX, Chang E, Fawcett J, Kuchel G, Miller FD (1997) Synaptic innervation density is regulated by neuron-derived BDNF. Neuron 18:257-267.

Conner JM, Lauterborn JC, Yan Q, Gall CM, Varon S (1997) Distribution of brain-derived neurotrophic factor $(\mathrm{BDNF})$ protein and mRNA in the normal adult rat CNS-evidence for anterograde axonal transport. J Neurosci 17:2295-2313.

Dasheiff RM, McNamara JO (1982) Intradentate colchicine retards the development of amygdala kindling. Ann Neurol 11:347-352.

Davis S, Gale NW, Aldrich TH, Maisonpierre PC, Lhotak V, Pawson T, Goldfarb M, Yancopoulos GD (1994) Ligands for EPH-related receptor tyrosine kinases that require membrane attachment or clustering for activity. Science 266:816-819.

Dougherty KD, Milner TA (1997) Ultrastructural distribution of p75 neurotrophin receptor immunoreactivity in rat dentate gyrus. Soc Neurosci Abstr 23:335.

Dugich-Djordjevic MM, Tocco G, Lapchak PA, Pasinetti GM, Najm I, Baudry M, Hefti F (1992a) Regionally specific and rapid increases in brain-derived neurotrophic factor messenger RNA in the adult rat brain following seizures induced by systemic administration of kainic acid. Neuroscience 47:303-315.

Dugich-Djordjevic MM, Tocco G, Willoughby DA, Najm I, Pasinetti G,
Thompson RF, Baudry M, Lapchak PA, Hefti F (1992b) BDNF mRNA expression in the developing rat brain following kainic acidinduced seizure activity. Neuron 8:1127-1138.

Elmer E, Kokaia Z, Kokaia M, Carnahan J, Nawa H, Bengzon J, Lindvall O (1996) Widespread increase of brain-derived neurotrophic factor protein in the rat forebrain after kindling-induced seizures. Soc Neurosci Abstr 22:2089.

Elmer E, Kokaia M, Ernfors P, Ferencz I, Kokaia Z, Lindvall O (1997) Suppressed kindling epileptogenesis and perturbed BDNF and trkB gene regulation in NT-3 mutant mice. Exp Neurol 145:93-103.

Ernfors P, Bengzon J, Kokaia Z, Persson H, Lindvall O (1991) Increased levels of messenger RNAs for neurotrophic factors in the brain during kindling epileptogenesis. Neuron 7:165-176.

Figurov A, Pozzo-Miller LD, Olafsson P, Wang T, Lu B (1996) Regulation of synaptic responses to high-frequency stimulation and LTP by neurotrophins in the hippocampus. Nature 381:706-709.

Frank L, Ventimiglia R, Anderson K, Lindsay RM, Rudge JS (1996) BDNF downregulates neurotrophin responsiveness, trkB protein and trkB mRNA levels in cultured rat hippocampal neurons. Eur J Neurosci 8:1220-1230.

Funabashi T, Sasaki H, Kimura F (1988) Intraventricular injection of antiserum to nerve growth factor delays the development of amygdaloid kindling. Brain Res 458:132-136.

Gall C, Lauterborn J, Bundman M, Murray K, Isackson P (1991) Seizures and the regulation of neurotrophic factor and neuropeptide gene expression in brain. Epilepsy Res [Suppl] 4:225-245.

Gall CM (1993) Seizure-induced changes in neurotrophin expression: implications for epilepsy. Exp Neurol 124:150-166.

Gall CM, Isackson PJ (1989) Limbic seizures increase neuronal production of messenger RNA for nerve growth factor. Science 245:758-761.

Gall CM, Berschauer R, Isackson PJ (1994) Seizures increase basic fibroblast growth factor mRNA in adult rat forebrain neurons and glia. Mol Brain Res 21:190-205.

Glass DJ, Bowen DC, Stitt TN, Radziejewski C, Bruno J, Ryan TE, Gies DR, Shah S, Mattsson K, Burden SJ, DiStefano PS, Valenzuela DM, DeChiara TM, Yancopoulos GD (1996) Agrin acts via a MuSK receptor complex. Cell 85:513-523.

Goddard GV, McIntyre DC, Leech CK (1969) A permanent change in brain function resulting from daily electrical stimulation. Exp Neurol 25:295-330.

Hubel DH, Wiesel TN (1965) Binocular interaction in striate cortex of kittens reared with artificial squint. J Neurophysiol 28:1041-1059.

Humpel C, Wetmore C, Olson L (1993) Regulation of brain-derived neurotrophic factor messenger RNA and protein at the cellular level in pentylenetetrazol-induced epileptic seizures. Neuroscience 53:909-918.

Humpel C, Hoffer B, Stromberg I, Bektesh S, Collins F, Olson L (1994) Neurons of the hippocampal formation express glial cell line-derived neurotrophic factor messenger RNA in response to kainate-induced excitation. Neuroscience 59:791-795.

Humpel C, Lindqvist E, Soderstrom S, Kylberg A, Ebendal T, Olson L (1995) Monitoring release of neurotrophic activity in the brains of awake rats. Science 269:552-554.

Ip NY, Stitt TN, Tapley P, Klein R, Glass DJ, Fandl J, Greene LA, Barbacid M, Yancopoulos GD (1993) Similarities and differences in the way neurotrophins interact with the trk receptors in neuronal and nonneuronal cells. Neuron 10:137-149.

Isackson PJ, Huntsman MM, Murray KD, Gall CM (1991) BDNF mRNA expression is increased in adult rat forebrain after limbic seizures: temporal patterns of induction distinct from NGF. Neuron 6:937-948.

Kang H, Schuman EM (1995) Long-lasting neurotrophin-induced enhancement of synaptic transmission in the adult hippocampus. Science 267:1658-1662.

King GL, Dingledine R, Giacchino JL, McNamara JO (1985) Abnormal neuronal excitability in hippocampal slices from kindled rats. J Neurophysiol 54:1295-1304.

Klein R, Jing SQ, Nanduri V, O'Rourke E, Barbacid M (1991) The trk proto-oncogene encodes a receptor for nerve growth factor. Cell 65:189-197.

Knusel B, Rabin S, Widmer HR, Hefti F, Kaplan DR (1992) Neurotrophin-induced trk receptor phosphorylation and cholinergic neuron response in primary cultures of embryonic rat brain neurons. NeuroReport 3:885-888.

Kokaia M, Ernfors P, Kokaia Z, Elmer E, Jaenisch R, Lindvall O (1995) 
Suppressed epileptogenesis in BDNF mutant mice. Exp Neurol 133:215-224

Korte M, Carroll P, Wolf E, Brem G, Thoenen H, Bonhoeffer T (1995) Hippocampal long-term potentiation is impaired in mice lacking brainderived neurotrophic factor. Proc Natl Acad Sci USA 92:8856-8860.

Korte M, Griesbeck O, Gravel C, Carroll P, Staiger V, Thoenen H, Bonhoeffer T (1996) Virus-mediated gene transfer into hippocampal CA1 region restores long-term potentiation in brain-derived neurotrophic factor mutant mice. Proc Natl Acad Sci USA 93:12547-12552.

Larmet Y, Reibel S, Carnahan J, Nawa H, Marescaux C, Depaulis A (1995) Protective effects of brain-derived neurotrophic factor on the development of hippocampal kindling in the rat. NeuroReport 6:1937-1941.

Lee TH, Kato H, Pan LH, Ryu JH, Kogure K, Itoyama Y (1998) Localization of nerve growth factor, trkA and p75 immunoreactivity in the hippocampal formation and basal forebrain of adult rats. Neuroscience 83:335-349.

Levine ES, Dreyfus CF, Black IB, Plummer MR (1995) Differential effects of NGF and BDNF on voltage-gated calcium currents in embryonic basal forebrain neurons. J Neurosci 15:3084-3091.

Lindvall O, Kokaia Z, Bengzon J, Elmer E, Kokaia M (1994) Neurotrophins and brain insults. Trends Neurosci 17:490-496.

Lohof AM, Ip NY, Poo MM (1993) Potentiation of developing neuromuscular synapses by the neurotrophins NT-3 and BDNF. Nature 363:350-353.

Lowenstein DH, Arsenault L (1996) The effects of growth factors on the survival and differentiation of cultured dentate gyrus neurons. J Neurosci 16:1759-1769.

Lowenstein DH, Seren MS, Longo FM (1993) Prolonged increases in neurotrophic activity associated with kainate-induced hippocampal synaptic reorganization. Neuroscience 56:597-604.

Maffei L, Berardi N, Domenici L, Parisi V, Pizzorusso T (1992) Nerve growth factor (NGF) prevents the shift in ocular dominance distribution of visual cortical neurons in monocularly deprived rats. J Neurosci 12:4651-4662.

McAllister AK, Lo DC, Katz LC (1995) Neurotrophins regulate dendritic growth in developing visual cortex. Neuron 15:791-803.

McAllister AK, Katz LC, Lo DC (1996a) Neurotrophin regulation of cortical dendritic growth requires activity. Neuron 17:1057-1064.

McAllister AK, Lo DC, Katz LC (1996b) Endogenous trkB ligands regulate dendritic growth in developing visual cortex. Soc Neurosci Abstr 22:277.

McNamara JO, Bonhaus DW, Shin C (1993) The kindling model of epilepsy. In: Epilepsy: models, mechanisms, and concepts (Schwartzkroin PA, ed), pp 27-47. New York: Cambridge UP

Merlio JP, Ernfors P, Kokaia Z, Middlemas DS, Bengzon J, Kokaia M, Smith ML, Siesjo BK, Hunter T, Lindvall O, Persson H (1993) Increased production of the trkB protein tyrosine kinase receptor after brain insults. Neuron 10:151-164.

Mudo G, Jiang XH, Timmusk T, Bindoni M, Belluardo N (1996) Change in neurotrophins and their receptor mRNAs in the rat forebrain after status epilepticus induced by pilocarpine. Epilepsia 37:198-207.

Nawa H, Carnahan J, Gall C (1995) BDNF protein measured by a novel enzyme immunoassay in normal brain and after seizure: partial disagreement with mRNA levels. Eur J Neurosci 7:1527-1535.

Osehobo P, Adams B, Sazgar M, Verdi J, Racine R, Fahnestock M (1996) Effects of in vivo BDNF infusion on amygdala kindling, sprouting, and hilar area. Soc Neurosci Abstr 22:995.

Pardridge WM (1991) Peptide drug delivery to the brain. New York: Raven.

Patel MN, McNamara JO (1995) Selective enhancement of axonal branching of cultured dentate gyrus neurons by neurotrophic factors. Neuroscience 69:763-770.

Patel M, Day BJ, Crapo JD, Fridovich I, McNamara JO (1996) Requirement for superoxide in excitotoxic cell death. Neuron 16:345-355.

Patterson SL, Abel T, Deuel TA, Martin KC, Rose JC, Kandel ER (1996) Recombinant BDNF rescues deficits in basal synaptic transmission and hippocampal LTP in BDNF knockout mice. Neuron 16:1137-1145.

Paxinos G, Watson C (1982) The rat brain in stereotaxic coordinates. Sydney: Academic.

Purves D (1988) Body and brain: a trophic theory of neural connections. Cambridge, MA: Harvard UP.

Purves D (1994) Neural activity and the growth of the brain. Cambridge, UK: Cambridge UP.
Racine RJ (1972) Modification of seizure activity by electrical stimulation. II. Motor seizure. Electroenceph Clin Neurophysiol 32:281-294.

Rashid K, Van der Zee CE, Ross GM, Chapman CA, Stanisz J, Riopelle RJ, Racine RJ, Fahnestock M (1995) A nerve growth factor peptide retards seizure development and inhibits neuronal sprouting in a rat model of epilepsy. Proc Natl Acad Sci USA 92:9495-9499.

Reibel S, Larmet Y, Le BT, Carnahan J, Nawa H, Marescaux C, Depaulis A (1996) Protective effects of brain-derived neurotrophic factor in two models of epilepsy in the rat. Soc Neurosci Abstr 22:996.

Rong YQ, Baudry M (1996) Seizure activity results in a rapid induction of nuclear factor-kappa-B in adult but not juvenile rat limbic structures. J Neurochem 67:662-668.

Routbort MJ, McNamara JO (1996) Excitatory amino acids and usedependent plasticity: epileptogenesis. In: Excitatory amino acids and the cerebral cortex (Conti F, Hicks TP, eds), pp 313-323. Cambridge, MA: MIT

Routbort MJ, Ryan TE, Yancopoulos GD, McNamara JO (1997) TrkBIgG does not inhibit mossy fiber sprouting in an in vitro model. Soc Neurosci Abstr 23:888.

Saffran BN, Woo JE, Mobley WC, Crutcher KA (1989) Intraventricular NGF infusion in the mature rat brain enhances sympathetic innervation of cerebrovascular targets but fails to elicit sympathetic ingrowth. Brain Res 492:245-254.

Sato K, Kashihara K, Morimoto K, Hayabara T (1996) Regional increases in brain-derived neurotrophic factor and nerve growth factor mRNAs during amygdaloid kindling, but not in acidic and basic fibroblast growth factor mRNAs. Epilepsia 37:6-14.

Scharfman HE (1997) Hyperexcitability in combined entorhinal/hippocampal slices of adult rat after exposure to brain-derived neurotrophic factor. J Neurophysiol 78:1082-1095.

Schlessinger J, Ulrich A (1992) Growth factor signaling by receptor tyrosine kinases. Neuron 9:381-391.

Schmidt-Kastner R, Olson L (1995) Decrease of neurotrophin-3 mRNA in adult rat hippocampus after pilocarpine seizures. Exp Neurol 136:199-204

Schwartz PM, Borghesani PR, Levy RL, Pomeroy SL, Segal RA (1997) Abnormal cerebellar development and foliation in BDNF $-/-$ mice reveals a role for neurotrophins in CNS patterning. Neuron 19:269-281.

Segal RA, Bhattacharyya A, Rua LA, Alberta JA, Stephens RM, Kaplan DR, Stiles CD (1996) Differential utilization of trk autophosphorylation sites. J Biol Chem 271:20175-20181.

Shelton DL, Sutherland J, Gripp J, Camerato T, Armanini MP, Phillips HS, Carroll K, Spencer SD, Levinson AD (1995) Human trks: molecular cloning, tissue distribution, and expression of extracellular domain immunoadhesins. J Neurosci 15:477-491.

Stitt TN, Conn G, Gore M, Lai C, Bruno J, Radziejewski C, Mattsson K, Fisher J, Gies DR, Jones PF, Masiakowski P, Ryan TE, Tobkes NJ, Chen DH, Distefano PS, Long GL, Basilico C, Goldfarb MP, Lemke G, Glass DJ, Yancopoulos GD (1995) The anticoagulation factor protein S and its relative, Gas6, are ligands for the Tyro 3/Axl family of receptor tyrosine kinases. Cell 80:661-670.

Stoop R, Poo MM (1996) Synaptic modulation by neurotrophic factors: differential and synergistic effects of brain-derived neurotrophic factor and ciliary neurotrophic factor. J Neurosci 16:3256-3264.

Sutula T, He XX, Cavazos J, Scott G (1988) Synaptic reorganization in the hippocampus induced by abnormal functional activity. Science 239:1147-1150.

Tanaka T, Saito H, Matsuki N (1997) Inhibition of GABAa synaptic responses by brain-derived neurotrophic factor (BDNF) in rat hippocampus. J Neurosci 17:2959-2966.

Timmusk T, Belluardo N, Metsis M, Persson H (1993) Widespread and developmentally regulated expression of neurotrophin-4 mRNA in rat brain and peripheral tissues. Eur J Neurosci 5:605-613.

Van Der Wal EA, Gomez-Pinilla F, Cotman CW (1994) Seizureassociated induction of basic fibroblast growth factor and its receptor in the rat brain. Neuroscience 60:311-323.

Van der Zee CE, Rashid K, Le K, Moore KA, Stanisz J, Diamond J, Racine RJ, Fahnestock M (1995) Intraventricular administration of antibodies to nerve growth factor retards kindling and blocks mossy fiber sprouting in adult rats. J Neurosci 15:5316-5323.

Yan Q, Rosenfeld RD, Matheson CR, Hawkins N, Lopez OT, Bennett L, Welcher AA (1997) Expression of brain-derived neurotrophic factor protein in the adult rat central nervous system. Neuroscience 78: $431-448$. 